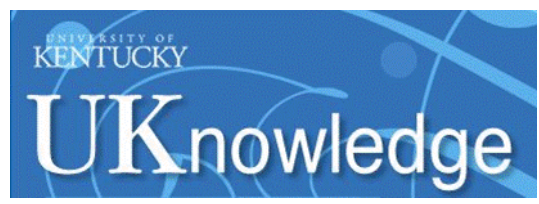

Kentucky Law Journal

\title{
Love's Labor's Lost: Marry for Love, Copyright Work Made-for-Hire, and Alienate at your Leisure
}

Llewellyn Joseph Gibbons

University of Toledo College of Law

Follow this and additional works at: https://uknowledge.uky.edu/klj

Part of the Family Law Commons, and the Intellectual Property Law Commons

Right click to open a feedback form in a new tab to let us know how this document benefits you.

\section{Recommended Citation}

Gibbons, Llewellyn Joseph (2012) "Love's Labor's Lost: Marry for Love, Copyright Work Made-for-Hire, and Alienate at your Leisure," Kentucky Law Journal: Vol. 101: Iss. 1, Article 6.

Available at: https://uknowledge.uky.edu/klj/vol101/iss1/6

This Article is brought to you for free and open access by the Law Journals at UKnowledge. It has been accepted for inclusion in Kentucky Law Journal by an authorized editor of UKnowledge. For more information, please contact UKnowledge@lsv.uky.edu. 


\title{
Love's Labor's Lost: Marry for Love, Copyright Work Made-for-Hire, and Alienate at your Leisure
}

\author{
Llezellyn Joseph Gibbons' \\ What's love got to do, got to do with it? \\ What's love but a sweet old-fashioned notion? \\ -Tina Turner ${ }^{2}$

\section{INTRODUCTION}

Federal and state courts have fecklessly faced the vexatious problem of allocating federal rights in copyrights created during a marriage using principles of state law. ${ }^{3}$ Copyrights are property rights that are created under federal law and whose initial ownership is governed exclusively by federal law. ${ }^{4}$ Strong Congressionally declared federal public policies relating to balancing public (user) rights and author incentives strive to create a uniform national copyright regime. ${ }^{5}$ On the other hand, marriage is a uniquely state institution, and federal and state courts have indulged in every permissible presumption in order to avoid finding state laws governing marriage, marital property, and its status at the dissolution of the

I Associate Professor, University of Toledo College of Law. The author would like to thank his research assistant John Powers and acknowledge the valuable comments of participants of the University of Toledo College of Law 20 ro Half-Baked Ideas Workshop; Franklin Pierce Intellectual Property Law Center (University of New Hampshire) Inaugural Intellectual Property Academic Conference; 20 I I Annual Meeting Central States Law School Association; the Drake University School of Law 2012 Intellectual Property Scholars Roundtable; and Professors Ann Bartow and Marina Angel, for their succinct advice. Finally, the author would like to thank the editors and staff of the Kentucky Law. Journal for their hard work and many useful editorial suggestions that improved this article immeasurably. As always, the opinions expressed in this article as well as the many errors and omissions are solely the responsibility of the author despite the hard work of his administrative assistant Diane Bohn to save him from his own errors.

2 Tina Turner, What's Love Got to Do with It, on Private Dancer (Capitol Records I984).

3 See, e.g., Rodrigue v. Rodrigue (Rodrigue II), 218 F.3d 432, 433 (5th Cir. 2000); Worth v. Worth (In re Marriage of Worth), 24! Cal. Rptr. 135, 136 (Cal. Ct. App. 1987); In re Marriage of Heinze, 631 N.E.2d 728, 729 (IIl. App. Ct. 1994); Boutz v. Donaldson, 99I P.2d 517, 524-25 (N.M. 1999).

4 See 17 U.S.C. $\$ 20 \mathrm{I}(\mathrm{a})$ (2006) ("Copyright ... vests initially in the author ....").

5 See Cmty. for Creative Non-Violence v. Reid, 490 U.S. 730, 740 (1989); H.R. Rep. No. 94-1476, at 47 (1976), reprinted in 1976 U.S.C.C.A.N. 5659, 5659-60. 
marriage preempred by federal law. ${ }^{6}$ In order to do justice, if not law, courts have been remarkably creative in finding novel procrustean interpretations of copyright law in a vain attempt to harmonize Congress's statutory commands with sui generis state community property law principles. ${ }^{7}$.

This article will consider who owns a copyright created by an authorspouse (or cohabiting partner) during the relationship and then analyze whether substituting the romantic institution of the marriage partnership with a business entity partnership may yield a result that is more consistent with the statutory norms of copyright law. This article will focus on the copyright issues that arise in a community property jurisdiction in the context of dissolution proceedings. However, the potential application of its thesis is much wider and, in principle, may apply equally as well in common law jurisdictions using an equitable distribution model; ${ }^{8}$ in states providing some legal protections for cohabitating individuals, for example,

6 See Hisquierdo v. Hisquierdo, 439 U.S. 572, 58 I (1979) (citing United States v. Yazell, 382 U.S. 34I, 352 ( 1966 )) ("State family and family-property law must do 'major damage' to 'clear and substantial' federal interests before the Supremacy Clause will demand that state law be overridden."); United Ass'n of Journeymen v. Myers, 488 F. Supp. 704,707 (M.D. La. 1980) ("We start with the proposition that the delicate relationships of husband-wife, parentchild and family-property arrangements are traditionally matters of exclusive state concern. No provision of Article I of the Constitution confers power upon the Congress to legislate in these sensitive state fields. Any general federal law attempting to regulate such relationships would be constitutionally infirm. If the Tenth Amendment reserved any powers to the states, it must be the power to legislate the rules applicable to marriage, separation and divorce, community property and succession."), aff'd, 645 F.2d 532 (5th Cir. 1981).

7 Set Francis M. Nevins, Jr., When an Author's Marriage Dies: The Copyright-Divorce Connection, 37 J. Copyright Soc'v U.S. 382, 397-98 (1990).

8 See, e.g., Teller v. Teller, 53 P.3d 240, 246-47 (Haw. 2002); In re Marriage of Heinze, 631 N.E.2d at 731 (stating that the definition of marital property in Illinois, a common law jurisdiction, "is very similar to California's definition of community property[l" when dividing royalties from books written during marriage); see also Ann Bartow, Intellectual Property and Domestic Relations: Issues to Consider When There Is an Artist, Author, Inventor, or Celebrity in the Family, 35 FAM. L.Q. 383, 412 \& n.152 (2001) (noting that characterization of copyrights for divorce purposes will arisc in the context of equitable distribution); Nevins, Jr., supra note 7, at 388 (highlighting the presence of the preemption problem in equitable distribution jurisdictions as well as community property jurisdictions). 
a meretricious relations state; ${ }^{9}$ or in states following the California Supreme Court's seminal holding in Marvin v. Marvin. ${ }^{10}$

This article concludes that a less romantic view of the commerce of the marital relationship and a more commercial view of romantic marriage as a business entity will better effectuate the public policies concerning marriage as an economic institution and the use of copyrights' constitutional polices to promote the progress of science and the useful arts. Courts should not change their understanding of the general laws governing copyright; rather, courts should adopt a realistic understanding of marriage as the legal and functional equivalent of a business entity partnership and treat the authorspouse's copyrighted works as a work-made-for-hire under the Copyright Act. Courts have had centuries of experience addressing the economic rights and obligations of a couple at the dissolution of their marriage when the marital assets consisted of mostly tangible property. ${ }^{11}$ Modern wealth is no longer necessarily based solely on titles to real estate or ownership of tangible objects; it can include wealth from intangible rights, including intellectual property or other new forms of property. ${ }^{12}$ While the law of real and personal property is largely a state body of law, often the law governing intangible rights in the area of copyright is federal law. ${ }^{13}$

9 Under Washington law, “'[a] meretricious relationship is a stable, marital-like relationship where both parties cohabit with knowledge that a lawful marriage between them does not exist." Soltero v. Wimer, I 50 P.3d 552, 555 (Wash. 2007) (quoting Connell v. Francisco, 898 P.2d $83 \mathbf{I}, 834$ (Wash. 1995)). Only property deemed community property in a marriage is subject to a just and equitable distribution upon dissolution of a meretricious relationship. Id. \& n.3. So, Washington's meretricious relationship law also potentially poses the same problems that community properry laws pose for the post-marital allocation of copyrights. See Gavin M. Parr, What Is a "Meretricious Relationship"?: An Analysis of Cohabitant Property Rights Under Connell v. Francisco, 74 WASH. L. REv. 1243, I 252 (1999) (describing the meretricious relationship as having a "pseudo-community property" character).

10 See Marvin v. Marvin, 557 P.2d 106, I 10 (Cal. 1976) ("In the absence of an express contract, the courts should inquire into the conduct of the parties to determine whether that conduct demonstrates an implied contract, agreement of partnership or joint venture, or some other tacit. understanding between the parties. The courts may also employ the doctrine of quantum meruit, or equitable remedies such as constructive or resulting trusts, when warranted by the facts of the case.") (emphasis added). See generally Howard O. Hunter, Modern Law of Contracts $\S 24: 7$ (2012) (discussing cases following Marvin as applied in Nevada, Maryland, Missouri, Arizona, Wisconsin, District of Columbia, New Jersey, Oregon, and Colorado).

1 I See, e.g., Stockton v. Knock, I5 P. 51, 52 (Cal. I 887); Palmer v. Palmer, I Paige Ch. 276, 277-78 (N.Y. Ch. 1828); Trimble v. Trimble, I 5 Tex. 18 , 19 (1855).

I See generally Susan Eisenberg, Intangible Takings, 60 VAND. L. Rev. 667, 696-700 (2007) (elaborating on the concept of virtual property); Allen M. Parkman, The Recognition of Human Capital as Property in Divorce Settlements, 40 ARK. L. Rev. 439, 440-4 I (I987) (highlighting the impact of human capital on divorce property settlements); Sally Brown Richardson, How Community Property Jurisdictions Can Avoid Being Lost in Cyberspace, 72 LA. L. Rev. 89, 9 I-I00 (20 I I) (discussing virtual property in the context of social media).

I3 Raymond T. Nimmer \& Patricia A. Krauthaus, Secured Financing and Information Property Rights, 2 High TECH. L.J. 195, 201 (1987). 
Naturally, changing existing copyright legislation would be a much simpler solution than reconsidering the centuries-old conception of marriage to conform it to modern principles of partnership and copyright law. ${ }^{14}$ So far, though, Congress has shown little inclination to change the existing Copyright Act. Further, the preemption problems presented by this article as justification for its solution are easily skirted through the use of prenuptial or postnuptial agreements. ${ }^{15}$ As an alternative to congressional action, the federal courts could craft a rule of federal common law to displace state law in this area. Further, state legislatures or state courts could determine as a matter of state law that copyrights are separate property or otherwise out of the marital estate when awarding marital property. As of the writing of this article, none of these alternative solutions appear to be under consideration.

\section{The Domestic Relations Problem}

Under state law domestic relations paradigms, state courts face questions of federal preemption when forced to allocate an author-spouse's or author-cohabitant's copyright assets in the course of adjudicating property claims arising out of the winding-up of a legally cognizable relationship. ${ }^{16}$ There are three predominant legal models of domestic relations that govern the post-dissolution allocation of property accumulated during the relationship. Individual states may be roughly divided into two groups: states where the economic relationship between spouses is defined by principles arising out of the common law, and states whose marital laws governing the economic relationship between spouses arise out of the civil law ("community property" states). ${ }^{17}$ While there are two distinct

14 See Rodrigue v. Rodrigue (Radrigue I) 55 F. Supp. 2d 534, 547 (E.D. La. 1999), ree'd on other grounds, 2 I 8 F.3 432 (5th Cir. 200o).

I5 See Nevins, Jr., supra note 7, at 406; Lee-ford Tritt, Liberating Estates Law from the Constraints of Copyright, 38 Rutgers L.J. 109, I80 (2006).

i6 See Principles of the Law of Family Dissolution: Analysis and Recommendations $\S 6.05$ (2002) ("Domestic-partnership property should be divided according to the principles set forth for the division of marital property in $\S 4.09$ and $\S 4$.ro."). Further discussion of meretricious relationships, Marvin $v$. Marvin cohabitation agreements, and the Principles of the Law of Family Dissolution would unnecessarily lengthen an already exceedingly verbose law review article.

17 The following states are essentially "community property" states: Arizona, California, Idaho, Louisiana, Nevada, New Mexico, Texas, Washington, and Wisconsin. E.g., William Bassett, Bassett on California Community Property LaW $\$ 1: 4$ (20I 1 ed.). For the purposes of the Copyright Act, Puerto Rico, a civil law jurisdiction, is considered a state. I 7 U.S.C. $\S$ I01 (2006). In Alaska, the couple may voluntarily agree in writing to treat property acquired after marriage as community property. See Alaska STat. $\$ 34.77 .030$ (20 Io). Moreover, some non-community property states recognize community property rights that were created while the married couple was living in a community property state. See, e.g., JoHn Parker Huggard, North Carolina Estate Settlement Practice Guide \$ 30:8 (2012). 
bodies of family property law, the two systems have some similarities, and some common law jurisdictions borrow "community property" definitions of marital property. ${ }^{18}$ So, judicial decisions in a community property jurisdiction may be persuasive authority in common law states. ${ }^{19}$ Also, there are states that recognize interests in property that is acquired during cohabitation under either the Marvin $v$. Marvin model or the meretricious relations model. ${ }^{20}$

\section{COPYRIGHT}

Since the enactment of the 1976 Copyright Act, the legal ownership of a copyright has been problematic because state laws governing "ownership" of a copyrighted work created during the marriage may deviate significantly from the federal norm of copyright ownership. ${ }^{21}$ Under the 1976 Copyright Act, copyright automatically subsists in original works of authorship fixed in a tangible medium of expression by or under the authority of the author ${ }^{22}$ and, at the moment of fixation, the copyright is immediately vested in the author. ${ }^{23}$.

The statutory norm for the transfer of a copyright ownership, other than by operation of law, is that the transfer is voluntary, in writing, and signed by the author or the author's agent. ${ }^{24}$ To be the owner of a copyright, one merely has to have an exclusive claim to any part of one or more of the rights granted to the author under $\S 106 .{ }^{25}$ However, the devil is in

I 8 See, e.g., In re Marriage of Heinze, 63 I N.E.2d 728, 731 (Ill. App. Ct. 1994) (finding Illinois's (common law jurisdiction) definition of marital property is "very similar to California's definition of community property[l" when dividing royalties to books written during marriage).

I9 Id. (describing California cases as persuasive).

20 See Marsha Garrison, Nonmatital Cohabitation: Social Revolution and Legal Regulation, 42 FAM. L.Q. 309, 315-16 (2008) ("Appellate courts in at least twenty-six states and the District of Columbia have now approved some relational contract claims [like that in Marvin v. Marvin] between cohabitants...."); Charlotte K. Goldberg, The Schemes of Adventuresses: The Abolition and Revival of Common-Law Marriage, 13 WM. \& MARY J. Women \& L. 483, 529-30 (2007) (discussing the meretricious relations model).

2 I To simplify the model discussed in this article, the copyrighted works described in the article were all initially created under the 1976 Act and published post-January 1, 1978. See Paul Goldstein, Goldstein on Copyright $\$ 4.0$ (Supp. 2012).

2217 U.S.C. $\S \mathrm{I02(a)}$ (2006). The term "fixed" is defined in 17 U.S.C. $\$ 101$.

2317 U.S.C. § 201 (a) (2006); N.Y. Times Co. v. Tasini, 533 U.S. 483, 493-94 (200I).

24 See 17 U.S.C. $\S 201(a)$, (e); Effects Assocs. v. Cohen, 908 F.2d 555, 556-57 (9th Cir. 1990). Transfers of permission to use the copyright that is less than "ownership," such as a non-exclusive license, may be done orally or in any other manner that conveys the copyright owner's assent to the use of the copyrighted work. See id. at 558.

25 '17 U.S.C. \& 10 I (2006) (“'Copyright owner,' with respect to any one of the exclusive rights comprised in a copyright, refers to the owner of that particular right:"). A narrow grant of an exclusive right to show a motion picture (\$ 106(3) public performance right) in a specific 
the details or in this case, in $\S 101$, the definition section. "A 'transfer of copyright ownership' is an assignment, mortgage, exclusive license, or any other conveyance, alienation, or hypothecation of a copyright or of any of the exclusive rights comprised in a copyright, whether or not it is limited in time or place of effect, [excluding] a nonexclusive license." 26

"Ownership" under copyright law is not congruent with the common lay usage of the term "ownership." For example, many non-copyright lawyers would not view a mortgage or a pledge of collateral under U.C.C. Article 9 as a transfer of ownership; however, these transactions are transfers of ownership under the Copyright Act. ${ }^{27}$ Under copyright law, the ownership of the intangible statutory bundle of rights granted to the author under $\S 106$ is legally distinct from the ownership of the tangible work which instantiates or fixes the copyright. ${ }^{28}$ In addition to acts of "assignment," "conveyance," and "alienation," the so-called lesser grants' of rights such as 'mortgage or hypothecation are also considered transfers of copyright ownership. ${ }^{29}$

Section 201(d) provides that the ownership of a copyright may be transferred by any means of conveyance, operation of law, bequest, or may pass as personal property through intestate succession. ${ }^{30}$ The "operation by law." provision of $\S 201(\mathrm{~d})$ is specifically limited by $\S 201(\mathrm{e})$ which expressly provides that

[w] hen an individual author's ownership of a copyright, or of any of the exclusive rights under a copyright, has not previously been transferred voluntarily by that individual author, no action by any governmental body or other official or organization purporting to seize, expropriate, transfer, or exercise rights of ownership with respect to the copyright, or any of the exclusive rights under a copyright, shall be given effect under this title, except as provided under title 11 [bankruptcy proceedings]. ${ }^{31}$

By its own terms, $\S 201(\mathrm{e})$ preempts all state laws purporting to transfer copyright ownership prior to the first voluntary grant by the individual

classroom (room 10I0) at the College of Law to a limited number of law students (not more than 20) between 7:30 and 9:30 pm on October 3, 201 2 constitutes a transfer of copyright ownership as long as there is a signed writing. See id. ("'transfer of copyright ownership' is.an ... exclusive license[] . . . of a copyright[,] ... whether or not it is limited in time or place of effect ...."); Effects Assocs., 908 F.2d at 556.

2617 U.S.C. $\$ 10 \mathrm{I}$.

27 Id.; In re World Auxiliary Power Co., 244 B.R. I49, I 5 I (Bankr. N.D. Cal. 1999).

28 I 7 U.S.C. $\$ 202$ (2006).

29 17 U.S.C. $\$$ 101. Hypothecation is roughly analogous to a lien or an agreement using collateral as security for a loan under U.C.C. Article 9. See In re Richman, I 8 I B.R. 260, 262-65 (Bankr. D. Md. 1995).

3017 U.S.C. \& $201(\mathrm{~d})(\mathrm{I})$ (2006); see also id. \$ 204(a). "[Section] 204(a) does not define the term 'operation of law."' Brooks v. Bates, 781 F. Supp. 202, 205 (S.D.N.Y. 1991 ).

3 I 17 U.S.C. $\$ 20$ I(e). 
author. ${ }^{32}$ Consequently, after the first voluntary transfer of a copyright by the author, the transferred copyright becomes merely another species of personal property that can be transferred by operation of state law from subsequent owners of the copyright. ${ }^{33}$

\section{Copyright As an Asset in Divorce}

In a community property state, marital property may be held either separately or as part of the community. Separate property belongs solely to the individual spouse. Community property belongs to the marital community, and upon dissolution of that community, the property must then be partitioned. ${ }^{34}$ If state law treated copyrights as separate property owned solely by the author-spouse then there would be no federal preemption issues. However, courts have found that through operation of state law, copyrights to works created during marriage were vested in the marital estate and therefore were subject to division upon dissolution of the marriage. ${ }^{35}$

This section will first review the dilemma posed by adjudicating rights to a federal copyright in a state court proceeding, then analyze the problems of adjudicating copyright ownership in the context of a community property state marriage dissolution proceeding. It will then review In re Marriage of Worth and Rodrigue $v$. Rodrigue, the two leading cases on the role of state law and copyright ownership in the context of marriage dissolution in two different community property states; analyze marital ownership rights in a copyrighted work created during the marriage; discuss the Copyright Act's three express preemption provisions (17 U.S.C. $§ 301(\mathrm{a}), 17$ U.S.C. $\S$ $301(\mathrm{f})$, and 17 U.S.C. $\$ 201(\mathrm{e})) ;{ }^{36}$ and conclude that state laws purporting to

32 Id. Section 201 (e) also appears to preclude involuntary transfers under federal law, except in the limited case of bankruptcy proceedings under Title 11 of the United States Code.

33 A leading commentator contends that a "transfer of ownership of copyright may be effectuated by 'operation of law' rather than by 'conveyance,' such operation of law must be triggered by the express or implied consent of the author." 3 MelviLle NIMMER \& DAvid Nimmer, NiMMer ON Copyrighr $\$ 10.03[a]$ (1997). Thus a $\$ 204$ (a) transfer by operation of law, unless voluntary, is constrained by $\$ 20 \mathrm{I}(\mathrm{e})$ 's prohibition against involuntary transfers. See Bates, 781 F. Supp. at 205.

34 See Judith T. Younger, Marital Regimes: A Story of Compromise and Demoralization, Together with Criticism and Suggestions for Reform, 67 CORNELL L. REv. 45, 79-81 (1981).

35 As noted by one commentator,

In recent years, all state courts [including those in equitable distribution juris-
dictions] that have addressed the issue have either assumed or have explicitly
held that copyrights, and the royalties therefrom, are marital (or communicy)
property to the extent that the copyrighted work or profits therefrom were gen-
erated by spousal labor during marriage.

2 Valuation and Distribution of Marital Property $\$ 23.07$ [1]-[2], at 23-1 20 to - I 21 (Matthew Bender \& Co. 2012).

36 See 2 William F., Patry on Copyright $\$$ i8:1 \& $\$$ 5:1 I6 (2012) [hereinafter Patry on 
transfer copyrights between married or cohabiting partners are preempted by the Copyright Act. ${ }^{37}$

\section{A. Exclusive Federal Court Copyright Jurisdiction, Exclusive State Court Marriage Dissolution Proceedings}

Many of the ownership issues presented by federal copyright law in a state divorce proceeding will never be properly adjudicated by a court of competent jurisdiction unless the underlying copyright dispute in the state-court case is ultimately determined by the United States Supreme Court. ${ }^{38}$ Federal courts have exclusive jurisdiction if the controversy requires a construction of the Copyright Act. ${ }^{39}$ Under the test established in T.B. Harms Co. v. Eliscu, an action arises under the Copyright Act "if the complaint is for a remedy expressly granted by the Act[] . . or asserts a claim requiring construction of the Act[] ... or, ... perhaps more doubtfully, presents a case where a distinctive policy of the Act requires that federal principles control the disposition of the claim." 40 Issues of authorship and ownership under copyright law, including whether consent to marry constitutes a voluntary prospective transfer of the copyright and whether there is a valid transfer of the copyright by operation of state law, are questions arising under the Copyright Act that require an authoritative construction of the Copyright Act. For this reason, the federal courts have exclusive subject matter jurisdiction. ${ }^{41}$ Unfortunately, while construction

CopyrighT] (copyright preemption provisions).

37 Compare 1-6A Melville Nimmer \& David Nimmer, Nimmer on Copyright § 6A.03[A] (20I2) [hereinafter Nimmer ON COPYRIGHT] ("Thus, despite the absence of any legislative history on the subject or decisional guidance over the many decades that copyright and community property have coexisted, logic would dictate that the community property laws should be held pre-empted."), with I-6A NimMER ON CopyrighT \$ 6A.03[C][2][b] ("Accordingly, the application of community property laws to copyrighted works stands or falls based on whether married authors have at least implicitly consented to transfers of their works. As already noted, one can plausibly maintain that such "consent" automatically accompanies the decision to marry. Absent such consent, however, Worth's holding cannot comply with the Copyright Act, and hence would clearly be pre-empted.") (footnote omitted).

38 See 5 Patry on Copyright, supra note 36, § 17:38. Cf. Minton v. Gunn, 355 S.W.2d 643 (Tex. 2011 ), cert. granted, 2012 WL 831493 (Oct. 5, 2012) (construing the analogous "arising under" provision in the patent context, noting that "other courts have deemed federal patent issues substantial when the determination of the patent issue establishes the success or failure of an overlying state-law claim," and holding that there was no state court jurisdiction in a state tort based attorney malpractice action requiring a construction of the "experimental use" exception in patent law).

39 T.B. Harms Co. v. Eliscu, 339 F.2d 823, 826 (2d Cir. I 964); see Int'l Armor \& Limousine Co. v. Moloney Coachbuilders, Inc., 272 F.3d 912, 915-16 (7th Cir. 2001).

40 T.B. Harms, 339 F.2d at 828 .

4 I See 5 Patry on Copyright, supra note 36 , § i 7:38; cf. Goodman v. Lee, 78 F.3d 1007 , 101 1-12 (5th Cir. 1996) (finding proper jurisdiction because the plaintiff sought to establish co-authorship under the Copyright Act, which necessitated interpretation of the ownership 
of the Copyright Act is vested exclusively in federal courts, construction of state family law statutes and adjudication of divorce proceedings are vested exclusively in the state courts. ${ }^{42}$

The statutory provisions granting federal courts exclusive jurisdiction over disputes arising under the Copyright Act and the prudential policies permitting the federal courts to avoid resolving family law matters that are best left to state court judges are not impermeable barriers to a resolution of copyright issues in community property states. ${ }^{43}$ The questions of copyright ownership that appear as part of the marital dissolution proceedings may also be brought as a declaratory judgment action in federal court, either separately litigated as part of a copyright infringement action or wholly removed from state to federal court. ${ }^{44}$ However, these issues will never be presented to a federal court as part of a divorce action. While under limited circumstances some federal courts may be permitted to certify a question of state law to state courts, ${ }^{45}$ there is no corresponding process that enables a state court to get an authoritative interpretation of the federal copyright laws from the federal courts (which are charged by Congress with the exclusive duty to interpret and to develop a uniform national body of copyright law). ${ }^{46}$

provisions of the Act); Merchant v. Levy, 92 F.3d 5 I, 56 (2d Cir. 1996) (stating that whether a work is a work-for-hire requires a construction of the Copyright Act). See also Minton v. Gunn, 355 S.W.2d 634, 639-40 (Tex. 2011 ) ("One form of 'arising under' federal-question jurisdiction stems from "state-law claims that implicate significant federal issues.") (citations omitted).

42 See United States v. Lopez, 5 I 4 U.S. 549, 563-65 (I 995) (limiting Congress's power to regulate family life under the Commerce Clause). The prudential reluctance of federal courts to involve themselves in state domestic relations matters is of long standing. See, e.g., Ex parte Burrus, 136 U.S. 586, 593-96 ( 1890 ); Barber v. Barber, 62 U.S. (2 I How.) 582, 603-05 ( 858 ).

43 See Grable \& Sons Metal Prods., Inc. v. Darue Eng'g \& Mfg., 545 U.S. 308, 314 (2005) ("...[B]ut neither have we treated 'federal issue' as a password opening federal courts to any state action embracing a point of federal law. Instead, the question is, does a state-law claim necessarily raise a stated federal issue, actually disputed and substantial, which a federal forum may entertain without disturbing any congressionally approved balance of federal and state judicial responsibilities.") (emphasis added); $c f$. De Sylva v. Ballentine, 351 U.S. 570,580 (1956) (discussing whether illegitimate children were statutory heirs under the 1909 Copyright Act).

44 See Rodrigue I, 55 F. Supp. 2d 534, 540-46 (E.D. La. 1999), rev'd on other grounds, Rodrigue $I I, 218 \mathrm{~F} .3 \mathrm{~d} 432,442$ (5th Cir. 2000), which addressed the issue of copyright ownership in the context of a summary judgment action. The issue may also arise in copyright infringement litigation since one of the elements of infringement is copyright ownership. See, e.g., Feist Publ'ns, Inc. v. Rural Tel. Serv. Co., 499 U.S. 340, 36I (1991). But of. Stein v. Soyer, No. 97 Civil I3 17 (MBM), 1997 WL 104967, at *1 (S.D.N.Y. Mar. 10, I997) (rejecting removal due to lack of a judiciable controversy).

45 See Bradford R. Clark, Ascertaining the Laws of the Several States: Positivism and Judicial Federalism After Erie, 145 U. PA. L. Rev. 1459, I 544 ( 1997) ("[F]orty-three states now permit at least some federal courts to certify unsettled questions of state law to the highest court of the state for authoritarive resolution.").

46 See Bruce M. Selya, Certified Madness: Ask a Silly Question . . , 29 Sufrolk U. L. Rev. 
Consequently, one significant flaw is that a copyright ownership dispute that requires an interpretation of federal law will never be settled until a federal court authoritatively adjudicates the issue. ${ }^{47}$ For example, if a state court awards copyright ownership to the spouse (instead of the actual author) then the issues of ownership may be re-litigated in federal court in a subsequent infringement action because ownership of the copyright is one element of a prima facie case of copyright infringement. ${ }^{48}$ This indeterminacy of title results in additional financial burdens on the parties, difficulties exploiting certain works because of their questionable title, and unnecessary collateral litigation. Regrettably, as the law now stands, federal copyright law and state domestic relations law will continue to develop as parallel and potentially inconsistent bodies of law regarding authorship and ownership of a copyright. This may require re-litigation of state law domestic relations awards in federal courts as collateral matters related to other copyright actions. ${ }^{49}$

\section{$B$. In re Marriage of Worth}

In re Marriage of Worth presented the first opportunity for either a state or federal court to opine on the ownership of the copyright (under the 1976 Copyright Act) of a work created during the marriage in a community property state..$^{50}$ In Worth, the parties had already agreed to allocate their respective interests in the royalties resulting from the copyrighted works created during the marriage. ${ }^{51}$ The author-spouse then commenced a copyright infringement action against the producers of the "Trivial Pursuit" board game. ${ }^{52}$ The then divorced-spouse commenced an action in the

$677,685-86$ (1995).

47 See I-6A Melville Nimmer \& David Nimmer, Nimmer on Copyright § 6A.o2 (1997); Armdap, Inc. v. Coast Bus. Sys., Inc., I 88 F.3d 51 2, 512 (9th Cir. 1999) (unpublished) ("Under the doctrine of res judicata, a final judgment on the merits only precludes the parties from relitigating issues that were raised or could have been raised in that action... [A] copyright claim could not have been raised in the state action because the federal courts have exclusive jurisdiction over claims arising under the copyright statute.").

48 See Feist Publ'ns, 499 U.S. at 36I (1991). 1996).

49 See Rodrigue v. Rodrigue, Civ. A. No. 95-2862, 1996 WL 109309, at *2-3 (E.D. La.

50 California has a sui generis statutory law of community property. See BASSETT, supra note 17, \& 1:4.

51 In re Marriage of Worth, 24I Cal. Rptr. 135, I35 (Cal. Ct. App. 1987). During the marriage, the husband wrote and published several books, including two books on trivia: The Complete Unabridged Super Trivia Encyclopedia (1977) and The Complete Super Trivia Encyclopedia, Volume II (1981). Id.

$5^{2}$ Id. 
California state court seeking an order for one-half of the proceeds, if any, from what ultimately was an unsuccessful copyright infringement action. ${ }^{53}$

The Worth court was then asked to reconcile California's community property law, which dictates that all property acquired during a marriage is community property, with $\S 201$ (a) of the 1976 Copyright Act, which "vests initial[]" ownership of the copyright in the individual author(s) ${ }^{54}$ California's community property law is based on a well-established partnership model in which each spouse makes a contribution to the marriage and shares alike in the wealth or assets accumulated during the term of the marriage. ${ }^{55}$ Copyright law on the other hand reflects a constitutional and statutory policy determination that if authors are granted a limited period of exclusivity to exploit the market for the copyrighted work, this economic incentive will promote the progress of science and the useful arts by encouraging authors to be more productive and to disseminate their works to the public. ${ }^{56}$

The Worth court relied on the terms of the prior stipulated judgment that the divorced-spouse would be entitled to one-half of the copyright royalties to conclude that the author-spouse also conceded that the copyrights were community property. ${ }^{57}$ The Worth court apparently conflated ownership of the tangible embodiment of the work with the ownership of the intangible copyright by holding that "[i]f the artistic work is community property, then it must follow that the copyright itself obtains the same status." 58 The Worth court then concluded that both the copyrights and the tangible benefits that flow from the copyright are community property. ${ }^{59}$

The Worth court without analysis considered the "vests initially" provision of $\S 201$ (a) in pari materia with $\S 201$ (d)(1), which provides that copyrights may pass by operation of law without considering either explicitly or implicitly the $\$ 201$ (e) limitation that any initial transfer of a copyright from the author must be voluntary, and then concluded that California's community property laws, simultaneously with the Copyright

53 Worth v. Selchow \& Righter Co., 827 F.2d 569, 570-71, 574 (9th Cir. 1987); Marriage of Worth, 241 Cal. Rptr. at $135 \&$ n. I.

54 See Marriage of Worth, 241 Cal. Rptr. at 136-37, 139.

55 Id. at 137.

56 Stewart v. Abend, 495 U.S. 207, 228-29 (1990); Sony Corp. v. Universal City Studios, Inc., 464 U.S. 417, 429 (1984) ("[The limited monopoly conferred by the Copyright Act] is intended to motivate the creative activity of authors and inventors by the provision of a special reward, and to allow the public access to the products of their genius after the limited period of exclusive control has expired.").

57 Marriage of Worth, 24I Cal. Rptt. at 138-39. Perhaps, a better interpretation is that the stipulated judgment represented fair economic terms on which to end a marriage rather than an acknowledgement of ownership of the property within the marriage.

$58 \mathrm{Id}$. at 137 .

59 Id. at 138 . 
Act vesting the author-spouse with the copyright, transferred an interest in the copyright to the non-author spouse through the marital community. ${ }^{60}$

Having concluded that federal law possibly permitted the transfer of a copyright from the vested-author to the community property estate, the Worth court then considered whether an author's incorporeal copyright was the type of intangible property that could be assigned through community property law. ${ }^{61}$ Some intangible assets such as a professional license are excluded in allocating community property because community property only exists prior to the dissolution of the marriage. ${ }^{62}$ The Worth court strived to distinguish a professional license to practice law, medicine, or a skilledtrade acquired during marriage from a copyright to a work created during the marriage by holding that "[a] copyright has a present value based upon the ascertainable value of the underlying artistic work. Its value normally would not depend on the postmarital efforts of the authoring spouse but rather on the tangible benefits directly or indirectly associated with the literary product." 63

This last bare assumption by the court regarding the ease of valuing a copyright and the lack of a need to cultivate a copyright's long term asset value is without citation and does not appear to comport with common sense or common business practices. ${ }^{64}$ This mistaken assumption regarding copyright valuation is inconsistent with the facts in the Worth case itself. The issue in the Worth case was, if the value of a copyright were to change because of a court judgment in a post-dissolution copyright infringement action, would the non-author spouse be entitled to a share of that judgment. In Worth, because of alleged copyright infringing acts by a third-party post-dissolution, the parties were now looking to a state court to allocate economic rights that may accrue only should the author-spouse eventually prevail in a federal court copyright infringement action. ${ }^{65}$

60 See Rodrigue I, 55 F. Supp. 2d 534, 537 n.2 (E.D. La. 1999) ("The only reported case [Marriage of Worth] on the subject concluded, with little analysis, that the Copyright Act does not preempt community property law."); Marriage of Worth, 241 Cal. Rptr. at 139.

61 Marriage of Worth, 24 I Cal. Rptr. at 138.

62 Id.

63 Id.

64 See In re Marriage of Heinze, 631 N.E.2d 728, 732 (Ill. App. Ct. I994) (valuing postdissolution efforts of a spouse to promote books); 2 Valuation and Distribution of Marital ProperTy \$ 23.07 [1], at 23-12I (Matthew Bender \& Co. 20I2) (discussing the valuation of intellectual property rights); $c f$. Yannas v. Frondistou-Yannas, 48I N.E.2d I I53, I 160 (Mass. 1985) (finding present value of future income too speculative to consider).

65 Marriage of Worth, 24 I Cal. Rptr. at 138-39; see also Rodrigue II, 218 F.3d 432, 434 (5th Cir. 2000). Further, because of the length of the copyright term, life of the author plus fifty years (now seventy years, see 17 U.S.C. $\$ \S 302-05(2006)$ ), there is an immense potential for new uses and new markets that were not considered at the time of the divorce. Cf. Boosey $\&$ Hawkes Music Publrs, Ltd, v. Walt Disney Co., I45 F.3d 481, 485 (2d Cir. 1998) (stating that the I940 movie Fantasia when re-released in home-video format (between I99I and 1998) grossed more than $\$ 360$ million). 
State-law-based claims to income derived from licensing a copyright have been raised in other family law contexts such as whether copyright income should be considered in calculating child support. In Boutz $v$. Donaldson, an author-spouse contended that the Copyright Act precluded a state court from considering the author's income from copyrighted works as income for the purposes of determining child support. ${ }^{66}$ The authorspouse erroneously contended that because copyrights are initially vested in the author under 17 U.S.C. $\$ 201$, copyrights are exclusively governed by 17 U.S.C. $\S 301$ rather than by the common law or statutes of any state; and because 17 U.S.C. $\$ 201(e)$ precludes a state from seizing a copyright, states are preempted from considering copyright income as an element in determining child-support obligations. ${ }^{67}$

The Donaldson court relied on Worth and held that income from the exploitation of a copyrighted work may be considered in determining the amount of a child support award. ${ }^{68}$ The Donaldson court's holding is less intrusive to the copyright rights of the author-spouse than the holding in Worth. The Donaldson court merely permitted the lower court to consider the royalty income, if any, as a factor in determining child support, while the Worth court shared the ownership of the copyright itself. ${ }^{69}$ Remember that $\S 201$ (e) expressly prohibits only involuntary transfers of a copyright; here, while not dispositive, the author-spouse had previously "consented in [the] original marital settlement agreement to include . . copyright income for purposes of child support[.]" ${ }^{70}$ In Donaldson, the copyright income was a result of a voluntary transfer of the copyright. The authorspouse's specious contention in Donaldson taken to its logical extreme would prohibit states from considering income derived from a copyright for state income tax purposes. Also, this contention would immediately fail in the context of the Internal Revenue Code, as Congress has expressed a clear and unambiguous statutory intent to tax copyright revenues. ${ }^{11}$

\section{Rodrigue v. Rodrigue}

Twelve years after Worth in Rodrigue v. Rodrigue, a federal court was first called upon to interpret copyright ownership in light of state community property law and to reconcile the obvious conflict between

66 Boutz v. Donaldson, 99 I P.2d 517,524 (N.M. Ct. App. I999).

67 Id.

$68 \mathrm{ld}$. at 525 .

69 Donaldson pre-dated the U.S. Court of Appeals for the Fifth Circuit's decision in Rodrigue. Rodrigue II, 2 I 8 F.3d 432; Donaldson, 99 I P.2d 5 I 7.

70 Donaldson, 991 P.2d at 524.

71 See Xuan-Thao Nguyen \& Jeffrey A. Maine, Equity and Efficiency in Intellectual Property Taxation, 76 Brook. L. Rev, I, I 8-2 I (2010). 
federal copyright law and state community property law. ${ }^{72}$ The district court was unable to harmonize the blatant conflict between Louisiana's state community property law and federal copyright law and held that the state law purporting to transfer a copyright was preempted. ${ }^{73}$ However, by unbundling and shuffling the bundle of sticks that comprised the author's copyright, the court of appeals was able to achieve some measure of harmonization between state and federal law and found that there was no federal preemption. ${ }^{74}$

1. Rodrigue v. Rodrigue I (U.S. District Court).-The district court in Rodrigue $v$. Rodrigue I started with the basic proposition that when divorce terminates the marriage, property belonging to the couple is subject to Louisiana's laws governing co-ownership. ${ }^{75}$ The non-author spouse contended that, by operation. of Louisiana community property law, $\S 201$ (d) of the Copyright Act made her a co-owner of the author-spouse's copyrights that subsisted during the marriage. ${ }^{76}$ The non-author spouse further asserted a claim for an accounting for the use of copyrighted images that were created during the marriage in any new derivative works painted after the dissolution of the marriage. ${ }^{77}$ If the copyright to these original works properly vested in the couple as community property, then any subsequent re-use of the copyrighted images should result in a royalty payment to the non-author spouse as a co-owner of the copyright to the original work. ${ }^{78}$

Louisiana law provides that until the community property is partitioned, "[e]ach spouse owns an undivided one-half interest in former community property and its fruits and products[.]"79 The author-spouse unnecessarily conceded before the district court that the divorced-spouse was entitled to an accounting for artworks created during the marriage; however, the author-spouse maintained that the divorced-spouse had no right to royalties from use of the reoccurring images in subsequent post-divorce-

72 See Rodrigue I, 55 F. Supp. 2d 534, 540 (E.D. La. 1999) (finding federal preemption of Louisiana community property law), ro'd, 2 I 8 F.3d 432, 440 (5th Cir. 2000) (straining to construe Louisiana community property law as consistent with the Copyright Act). The Rodrigues commenced their action in federal court as a declaratory judgment to adjudicate the disputed ownership of the copyright to works created by George Rodrigue during the marriage. Rodrigue $I I, 218$ F.3d at 434.

73 Rodrigue I, 55 F. Supp. $2 \mathrm{~d}$ at 547.

74 Rodrigue II, 2 I 8 F.3 d at 434-42.

75 Id. at $433-34$.

76 Id. at 434 .

77 Rodrigue I, 55 F. Supp. 2d at 536 n. I (referencing specifically the "Blue Dog" and "Jolie Blonde" images).

78 Rodrigue v. Rodrigue, Civ. A No. 95-2862, 1996 WL I09309, at *I (E.D. La. March 13, I996).

79 Rodrigue II, 218 F.3d at 434 (quoting LA. Civ. Code ANN. art. 2369.2 (20 Io)). 
partitioned artworks. ${ }^{80}$ The author-spouse disputed the divorced-spouse's claim to a percentage of the value of the post-dissolution artworks and contended that federal law vests the copyright solely in the author of the work and that there was no subsequent transfer of the copyright to the spouse or the marital community because Louisiana law does not authorize such a transfer. ${ }^{81}$ Additionally, any state law purporting to make such an involuntary transfer was preempted under $\S 201(\mathrm{e}) .^{82}$

In a cogent opinion with exhaustive citation to persuasive authority, the district court concluded that any attempt to transfer the author-spouse's copyright to the other spouse by an operation of state law was preempted either under $\S 201$ (e) or under the general copyright preemption provision $\S 301(a) .^{83}$ The court of appeals agreed with the district court that there was a conflict between state and federal law, but characterized the conflict as merely a "facial" conflict. ${ }^{84}$ Because the appeals court generally accepted the district court's factual and legal analysis while rejecting its ultimate conclusion that the conflict needed to be resolved by congressional action, this article will not further discuss the district court's sound analysis. ${ }^{85}$

2. Rodrigue v. Rodrigue II (U.S. Court of Appeals for the Fifth Circuit).-The judgment of the district court in Rodrigue I was reversed on other grounds. ${ }^{86}$ Through a myopic textual analysis of the Copyright Act, the United States Court of Appeals for the Fifth Circuit engaged in a Solomon-like maneuver to avoid finding more than a facial conflict between state and federal law. ${ }^{87}$ Because Rodrigue II is a federal court decision, this section will extensively discuss some of the many failings of the court's opinion in harmonizing the conflict between federal and state law as well as its weaknesses as a precedent under copyright right and domestic relations law.

80 Rodrigue I, 55 F. Supp. $2 \mathrm{~d}$ at 536.

81 Id. at 536-37.

82 Id. at 543 .

83 Id. at $540-43$.

84 Rodrigue $I I, 218 \mathrm{~F} .3 \mathrm{~d}$ at 435.

85 Id. at 434 .

86 See id. at $\mathbf{4 4 2}$ ("In the end, we disagree with the district court only to the extent that it held the conflict between Louisiana community property law and federal copyright law irreconcilable absent congressional intercession.").

87 Id. at 435-42; Dane S. Ciolino, How Copyrights Became Community Property (Sort of): Through the Rodrigue v. Rodrigue Looking Glass, 47 Lov. L. Rev. 631, 632 (2001) (describing the court as "constructing a curious new regime[,]" which was a resolution that neither party argued in the briefs before the court of appeals); F rancis M. Nevins, Jr., To Split or Not to Split: Judicial Divisibility of the Copyright Interests of Authors and Others, 40 FAM. L.Q. 499, 517 (2006) (depicting the Rodrigue appeals court as "boldly innovative and diabolically clever[]"). 


\section{a. Copyright Ownership (17 U.S.C. § 201(a))}

First, the Rodrigue II court interpreted the text of $\S 201$ (a) quite literally, reading it to convey only the exclusive right to the $\$ 106$ copyright without vesting the corresponding economic rights in the author. ${ }^{88}$ Under this interpretation, only the $\$ 106$ exclusive rights of reproduction, adaptation, publication, public performance, and public display were initially vested in the author ${ }^{89}$ Ignoring a long line of United States Supreme Court precedent, the Rodrigue II court then carefully noted that $\$ 201$ does not use the term "owner" or "ownership" nor does it refer to the concomitant economic rights of copyright ownership. ${ }^{90}$ Moreover, $\S 201$ (a) describes the status of joint authors as coowners of the copyright. So, this is a very strained interpretation of $\S 201(\mathrm{a}){ }^{91}$ Although citing Worth on the issue of the copyright vesting in the author, the Rodrigue II court then sub silencio rejected the Worth court's holding (or at least its legal analysis) and found that the author-spouse was the sole author and the other spouse was not a co-author under copyright law. ${ }^{92}$

\section{b. Voluntary Initial Transfer (17 U.S.C. \$201(e))}

Second, like the Worth court, the Rodrigue II court failed to address the pink elephant in the room by answering the question of whether there was an initial voluntary transfer under $\S 201(\mathrm{e}) .{ }^{93}$ Hypothetically, had the

88 Rodrigue II, 2 I 8 F.3d at 435-36. These property law principles may be sui generis to Louisiana as a civil code jurisdiction and severely limit Rodrigue $I I$ as persuasive authority in the Fifth Circuit, much less nationally. See Nevins, Jr., supra note 87, at 517-18.

89 Rodrigue II, 2 I 8 F.3d at 435-36.

90 Id.; see also Quality King Distribs. v. L'anza Research Int'l, 523 U.S. I35, I 4 1-42 (I998); Harper \& Row, Publ'rs, v. Nation Enters., 47 I U.S. 539, 546 (1985) ("Section 106 of the Copyright Act confers a bundle of exclusive rights to the owner of the copyright."); Sony Corp. v. Universal City Studios, Inc., 464 U.S. 417,432-33 (1984) (characterizing the author as "owner" of $\S 106$ rights); $q f$ I 7 U.S.C. $\$ 109$ (a) (2006) (describing the holder of $\S 106$ rights as a copyright owner via the first sale doctrine). It seems a bit incongruous that the Copyright Act $\S 201$ vests something less than ownership in the author but the author has the ability to grant a greater estate that comprises all the attributes of ownership, including economic rights. This violates the ancient doctrine of nemo dat qui non habet (no one may transfer more than he owns). Compare § 106, with § 201 (a).

9I See I7 U.S.C. $\$ 20$ I (a) (2006) ("Copyright in a work protected under this title vests initially in the author or authors of the work. The authors of a joint work are cooveners of copyright in the work.") (emphasis added).

92 Rodrigue II, 218 F.3d at 436 n.I 6. But see id. at 438 n.26.

93 There is only one citation to $\S 201(e)$ in the appellate opinion but no analysis of whether there was a voluntary transfer of the copyright to the marital estate. See id. at 44I n.47; of. Rodrigue I, 55 F. Supp. 2d 534, 542-44 (E.D. La. 1996) (analyzing the application of \& 20I(e) in great detail). This issue was raised in the appellate briefs. See Joint Brief for Appellees at 31-43, Rodrigue II, 218 F.3d 432 (5th Cir. 2000) (No. 99-30334). A charitable commentator may read into the court's silence that since Louisiana law explicitly permits married couples to opt 
Rodrigue II court interpreted $\S 201$ (e) so that there was a voluntary transfer of the copyright, then the logical result of Congress trying to protect dissent authors by shielding their copyrights from confiscation by the totalitarian government of the USSR was that Congress permitted the authors to retain control of the work's dissemination, but the copyright royalties, if any, would belong to the USSR under the $\S 201$ transfer by law provision. This author speculates that even the Rodrigue $I I$ court would agree that this would be an absurd result. While Rodrigue II's holding is arguably consistent with an allocation of community property under Louisiana law, ${ }^{94}$ it is unlikely that the Fifth Circuit would have reached the same result or even applied Rodrigue $I I$ as precedent had the government of the USSR appeared seeking its share of the royalties from the exploitation of the copyrights of dissent Soviet authors.

Dodging the clear preemption question presented by $\S 201(\mathrm{e}),{ }^{95}$ the Rodrigue II court then developed a novel and un-briefed theory of the case which used principles of Louisiana property law originally derived from Roman law and divided the author's copyright into functional property rights such as the "(1) usus-the right to use or possess," "(2) abusus-the right to abuse or alienate," and "(3) fructus-the right to the fruits . . ."96 Under the court's analysis, the author-spouse retained the $\S 106$ copyright grant of exclusive rights, including the rights of usus and abusus, while the fructus of the copyright was owned either jointly by the spouses or by the marital estate as a separate entity. ${ }^{97}$ The court then lumped intangible registered and unregistered federal copyrights into the Louisiana state property law category of "registered movables." 98 Under Louisiana law, if a good is "moveable," only one spouse has the right of use or alienation of it, but the marital community has the right to the profits arising from the use of property. ${ }^{99}$

into one of two property regimes either community property or separate with the community property regime being the default option that there was perhaps a colorable argument of voluntary choice. See La. Civ. Code AnN. arts. 2328-2329 (20 10).

94 But see, Ciolino, supra note 87 , at 638 n.36.

95 See Rodrigue I, 55 F. Supp. 2d at 542-44.

96 Rodrigue II, 2 I 8 F.3d at 437,438 . However, deciding an appeal sua sponte on grounds that were not briefed by the parties appears to be contrary to normal appellate court practice. See Singleton v. Wulff, 428 U.S. 106, 120 (1976) ("It is the general rule, of course, that a federal appellate court does not consider an issue not passed upon below."); Ciolino, supra note 87 , at 632 (commenting that this issue was neither briefed by the parties nor considered by the district court below).

97 Rodrigue II, 218 F.3 d at 437.

98 See id. at 438 .

99 Id. See generally J. Thomas Oldham, Everything Is Bigger in Texas, Except the Community Property Estate: Must Texas Remain a Divorce Haven for the Rich?, 44 FAM. L.Q. 293 (2010) (comparing community property laws). 


\section{c. Erie doctrine}

Third, the Fifth Circuit's procrustean use of Louisiana civil law to dismember the author's copyright may have run afoul of the Erie doctrine. ${ }^{100}$ Under Erie, federal courts are to look to the statutes and decisional law of the states to decide state law issues. ${ }^{101}$ Without citation to either legislative or judicial Louisiana state authority, the Rodrigue II court introduced a new and peculiar concept into Louisiana law: each spouse would get less than unconditional co-ownership of community property. ${ }^{102}$ The Rodrigue $I I$ court, while glomming on to selected black letter law provisions of the Louisiana statutes, did not consider these provisions as understood in the larger civil law tradition nor did it attempt to anticipate how the Louisiana Supreme Court would resolve these issues. Instead, the Rodrigue II court cited to a handful of black letter law cases on the trifold nature of property under Louisiana law: usus, abusus, and fructus. Yet the court did not appear to understand or appreciate the fundamental nature of each of these property rights. These rights are not severable. Louisiana community property law would vest full co-ownership in both spouses. ${ }^{103}$.

Another example of the court's wayward reasoning is the court's use of the term fructus in the copyright context. The nature of the fruits of a property right in Louisiana is much narrower than the use of the term by the Rodrigue $I I$ court. The issue in Rodrigue $I I$ was the right to royalties or payment for derivative works based on copyrighted works created during the marriage. Under the holding in Rodrique II, the author-spouse retained the rights of usus and abusus while the court partitioned the fructus. However, as a practical matter, the non-artist spouse's potential to accumulate wealth based on a claim to the fructus as an economic right is potentially very limited because under Louisiana law a transfer of an exclusive right that constitutes copyright ownership is not a fruit of the author's copyright. Rather, a copyright transfer is more properly characterized as a product of the author's copyright because a fructus is a transfer such as a non-exclusive license that does not significantly diminish the remaining substance of the underlying copyright. ${ }^{104}$ Once an exclusive right that the author possesses under copyright law is transferred, it is a right that the author no longer

I00 See Erie R.R. Co. v. Tompkins, 304 U.S. 64, 79 (1938).

IoI See Ciolino, supra note 87 , at 638 n.36 " It is uncertain whether the [Rodrigue II] court was confused about the effect of Louisiana property law in this regard, or simply decided to ignore the law as written and write its own Louisiana marital-property law.").

102 Id. at 639.

103 See La. Civ. Code AnN. arts. 2336, 2338 (2010); Ciolino, supra note 87, at $63^{8}$ n.36.

104 LA. Civ. Code AnN. art. 551 (2010); see Ciolino, supra note 87, at 654-55. The statement could be qualified if one considers the termination of transfer rights but, these rights were not explicitly addressed by the court. If one considers the right to terminate the transfer then perhaps the transfer may become a fruit. 
possesses unless or until the author or the author's statutory heirs exercise the author's right to terminate the transfer. ${ }^{105}$ So, the revenue from a sale or transfer of the copyright would belong to the author-spouse under a correct interpretation of Louisiana law. ${ }^{106}$

As one commentator concluded:

Ironically, the [Rodrigue $I I]$ court also failed as a matter of state community property law. By vesting only the copyright fructus in the community without the usis and abusus, the court denied the community the bulk of the economic benefits generated by copyrights - namely, economic benefits flowing from copyright use (usus) and transfer (abusus). Of course, the court easily could have captured these economic benefits for the community simply by declaring all copyrights to be co-owned community property with exclusive management authority in the authorspouse. Nevertheless, it chose not to do so. By fracturing ownership and allocating the dismembered parts the way it did, the court took away much of what it had hoped to give the nonauthor spouse. ${ }^{107}$

Of course, if the Rodrigue II court declared that all of the Copyright Act's $\S 106$ rights were community property, then its myopic interpretation of $\S 201$ 's vesting provision, as solely vesting exclusive copyright's property rights in the author but not the economic benefit of those rights, would fail.

\section{d. Registered Movables}

Fourth, another apparent misunderstanding by the Rodrigue II court is whether copyrights are "registered movables" under Louisiana law. ${ }^{108}$ While the Rodrigue II court is correct that as a matter of the efficient administration of the copyright estate, the economic management and control of the copyright should remain in the hands of the authorspouse; ${ }^{109}$ however, the Rodrigue II court erred when it held that copyrights are "registered movables." 110 "Under Louisiana law, a "registered movable' is one "for which the registration scheme provided by law is one that purports to protect those who rely on the ownership inferences that come from registration or issuance in one's name." "111 There is no requirement to

10517 U.S.C. § 203 (2006); Ciolino, supra note 87, at 654-55.

I06 Ciolino, supra note 87 , at 655 .

I07 Id. at 662-63.

108 Ciolino, supra note 87 , at $645-46$.

109 Rodrigue II, 218 F.3d 432, 435, 438 (5th Cir. 2000).

I 10 Ciolino, supra note 87 , at 646 . Traditional examples of registered movables include motor vehicles, stocks, bonds, and negotiable instruments. See Katherine S. Spaht \& Richard D. Moreno, Matrimonial Regimes $\$ 5.7$, in Louisiana Civil Law Treatise (3d ed. 2007); see also LA. Civ. Code. ANN. art. $235 \mathrm{I} \mathrm{cmt.} \mathrm{b} \mathrm{(2009).}$

II Ciolino, supra note 87, at 646 (quoting Katherine S. Spaht \& Lee Hargrave, Matrimonial Regimes § 5.7, at 24I, in Louisiana Civil Law Treatise (2d ed. 1997)). See also 
register a copyright; and the vast majority of copyrights are never registered. Although federal copyright registration conveys significant benefits, under the 1976 Copyright Act federal registration is still optional. ${ }^{112}$ Federal copyrights are not necessarily registered movables under Louisiana law, but because the Fifth Circuit nonchalantly categorized them as such and assumed that Louisiana's domestic relations law governed the ownership of the copyright, each spouse-not just the author-spouse-has the right to manage or alienate the copyright for unregistered copyrighted works. ${ }^{113}$ This point is more than speculative because many of the disputed works before the court in Rodrigue were unregistered copyrighted works. ${ }^{114}$

\section{e. Derivative Works (17 U.S.C. § 106(2))}

Fifth, as a matter of sound copyright law and policy, it was erroneous for the Rodrigue II court to hold that if the author-spouse creates any new derivative works based on original works that were created during the marriage, the author-spouse must share the revenue from them. ${ }^{115}$ Under copyright law, the artist will always be free to create new interpretations of the original without paying royalties to the divorced-spouse. However, should the artist copy original expression from a work made during the marriage, this new work would be a derivative work. Under the holding in Rodrigue II, the divorced-spouse would then be entitled to a share of the proceeds from any economic exploitation of the new post-divorce derivative work. ${ }^{116}$

As "copyrights do not protect thematic concepts, the fact that the same subject matter may be present in two paintings does not prove copying or infringement." ${ }^{117}$ However, applying the copyright law prohibitions against

LA. Civ. Code ANN. art. 235 I (2009) ("A spouse has the exclusive right to manage, alienate, encumber, or lease movables issued or registered in his name as provided by law.").

I 12 Johnsion v. Jones, 149 F.3d 494, 505 (6th Cir. 1998); see Reed Elsevier, Inc. v. Muchnick, 130 S. Ct. 1237, 124I (2010) ("[ 17 U.S.C. \$ 4 I I (a)] requires copyright holders to register their works before suing for copyright infringement .... [and] is a precondition to filing a claim that does not restrict a federal court's subject-matter jurisdiction.").

i 3 See La. Civ. Code ANN. art. 2346 (2009) ("Each spouse acting alone may manage, control, or dispose of community property unless otherwise provided by law.").

114 Rodrigue I, 55 F. Supp. 2d 534, 536,546 n. I5 (E.D. La. I999) ("Civil Code article 235 I provides: 'A spouse has the exclusive right to alienate, manage, encumber, or lease movables issued or registered in his name as provided by law.' Article $235 \mathrm{I}$ would address the problem only when the author spouse has registered a copyright pursuant to $\$ 410$ of the Act. Equal management rules would still apply to unregistered copyrights.") (citations omitted).

I 5 Rodrigue $I I, 218$ F.3d 432, 439 (5th Cir. 2000).

I 6 Rodrigue II, 218 F.3d at 437, 439, 442; see Franklin Mint Corp. v. Nat'l Wildlife Art Exch., 575 F.2d 62, 63 (3d Cir, 1978).

117 Franklin Mint, 575 F.2d at 65. 
unauthorized derivative works in the context of thematic works is tricky. ${ }^{18}$ As the Third Circuit found, "the line between copying and appropriation is often blurred." 119 In the case of artists who continuously paint new works on the same theme, it may be extremely difficult to separate works that intentionally or subconsciously copy prior works from new original works that merely share a common theme and artistic style. ${ }^{120}$.

Perhaps the most famous example of a thematic artist is Claude Monet who painted numerous painting of the water lilies in his garden over a period of about thirty years. ${ }^{121}$ In Rodrigue, the artist created a signature image based on the family pet, a dog named Tiffany. ${ }^{122}$ Under copyright law, in the case of thematic artists such as Rodrigue who repeatedly return to the same artistic subject, the act of determining whether a new work is also derivative work requires a delicate factual and legal analysis. There must be an extraordinarily nuanced determination of both originality and potential copying among every one of the artist's subsequent works that shares a similar visual appeal and theme with prior works and is also executed in the same artistic manner. ${ }^{123}$ This subtle determination will have to be made, anew each time the artist creates a new work and the non-author spouse claims economic rights derived from the new work.

\section{f. Miscellaneous Copyright Law Interpretation Errors}

Sixth, the Rodrigue II court also gave short shrift to the other arguably meritorious contentions of the author-spouse. The Rodrigue II court avoided the thorny issue of title and co-ownership created by the Worth court by recognizing the Congress vested title to the copyright in the author-spouse. ${ }^{124}$ The Rodrigue II court rejected the author-spouse's second contention that subjecting economic rights of an author-spouse to different state domestic relations laws will damage the federal policy of predictability and uniformity in copyright law. ${ }^{125}$ As support for this proposition, the Rodrigue II court looked to other provisions of the Copyright

118 Id.

119 Id.

I 20 Ciolino, supra note 87 , at $65^{\circ} \&$ n.97.

I 21 See The New York Times, The New York Times Guide to Essential Knowledge: A Desk Reference for the Curious Mind 33 (3d ed. 2011) (providing examples of Monet's thematic collections, including the "Rouen Cathedral (1892-94), haystacks ( $1890-91$ ), and water lilies (painted over 30 years beginning in 1899)[1")); JEAN-Dominique ReY \& DENIS Rouart, Monet Water Lilies: The Complete Series 124 (2008).

122 Id. at 433; Ishaq Kundawala, Note, Rodrigue v. Rodrigue: The Fifth Circuit Aligns with Worth-Accepting Copyright as Community Property, 3 Tul. J. Tech. \& INTEll. Prop. 165, 165 (200I).

123 Ciolino, supra note 87 , at $65^{\circ}$.

I 24 Rodrigue II, 2 I 8 F.3 d at 44 I.

125 Id. 
Act where Congress had specifically allowed state law to govern or where Congress was silent, thus permitting state law to operate by default.(as long as state law was consistent with the federal purpose of copyright law).126

A further problem with Rodrigue II's analysis is its observation that copyrights are conveyed by "individual, non-uniform state contract laws[.]" ${ }^{127}$ However, as a practical matter, state contract law is remarkably uniform. ${ }^{128}$ The Copyright Act contains federal limitations on state contract law. The Copyright Act further provides a minimal level of contractual formalities such as a signed writing. ${ }^{129}$ Also, the federal courts have consistently intervened and created federal common law to assure that state contract law is congruent with federal copyright policies. ${ }^{130}$ So, state law could not deviate too far from national contract norms. Further contributing to uniformity, while state law requires consideration as an element of a valid contract, federal copyright law is prepared to validate contracts without consideration. ${ }^{131}$

The non-uniform state law contract analogy used by the Rodrigue II court does not withstand a careful analysis. Although contract law among the states is relatively stable and consistent, domestic relations laws that govern the allocation of property vary greatly among the common law equitable jurisdiction states and the community property stateseven within the eight community property states, there are significant differences. ${ }^{132}$ While the appeals court in Rodrigue $I I$ faced the simple problem of applying the law of one state to allocate property interests in

126 Id.

127 Id.

128 See Restatement (Second) of Contracts: Introduction 2 (198I); Gregory E. Maggs, Ipse Dixit: The Restatement (Second) of Contracts and the Modern Development of Contract Law, 66 Geo. WASH. L. Rev. 508, 510-13, 517 (1998).

129 See 17 U.S.C. $\$ 204$ (a); Effects Assocs. v. Cohen, 908 F.2d 555, 556-57 (9th Cir. 1990).

130 See, e.g., Cincom Sys., v. Novelis Corp., 581 F.3d 431, 436 (6th Cir. 2009) ("[W]hen interpreting intellectual property licenses[,] ... . [f]ederal common law governs 'questions with respect to the assignability of a patent [or copyright] license."'); Saturday Evening Post Co. v. Rumbleseat Press, Inc., 8 I6 F.2d I I9I, I 199-1 200 (7th Cir. 1987) (discussing whether a clause in a contract prohibiting the licensee to contest the validity of the copyright was enforceable under federal common law); In re Allech Plastics, Inc., 7 I B.R. 686, 689 (W.D. Tenn. I987) ("The rights of the patent owner to license the use of his invention is a creature of federal common law as is the right of the licensee to have the license construed."). Further, federal common law rather than state law governs conflict of law rules. See Itar-Tass Russian News Agency v. Russian Kurier, Inc., I 53 F.3d 82, 90 (2d Cir. 1998) (developing federal common law to decide a conflicts of law issue in a copyright case, where the Copyright Act does not contain a controlling provision).

13I See 17 U.S.C. \$ 205(d) (2006).

132 Kenneth W. Kingma, Property Division at Divorce or Death for Married Couples Migrating Between Common Law and Community Property States, 35 AM. C. TR. \& Est. Couns. J. 74, 76 \& n. I 9 (2009) (for an excellent table summarizing the differences, see $i d$. at 93 (App. A)); James R. Ratner, Distribution of Marital Assets in Community Property Jurisdictions: Equitable Doesn't Equal Equal, 72 LA. L. Rev. 21 , 2 I-24 (20 I I). 
copyrights, in an increasingly mobile society, more courts will likely be faced with the tormenting problem of having to decipher multiple different state laws to allocate rights in copyrights that accrued in different states at different points in time. ${ }^{133}$ "[T] is domiciled at the time property is acquired also determines the division of that property upon divorce." 134 Consequently, the allocation of interests in copyrights under state law of a peripatetic married couple at the time of divorce will not only frustrate the divorce court but also Congress's goal for a national uniform copyright law.

As support for its decision to include the fructus of the copyright as part of the marital estate, the Rodrigue II court noted that Congress permitted state law to govern the disposition of copyrights as part of testamentary or intestate succession. ${ }^{135}$ Unlike the issues before the Rodrigue court where there is no record of Congress considering the role of state domestic relations law in the allocation of copyrights, Congress explicitly considered whether to create a federal testamentary and intestate succession scheme in the Copyright Act and elected to defer to state law. ${ }^{136}$ However, pragmatism, not deference to the unique role of the state law in the area of trusts and estates, was a driving force behind this occasion of deference; whatever copyright incentives Congress intended to grant to the author to promote the progress of science or the useful arts, those incentives cease to serve their purpose upon the death of the author. Further, by allocating the posthumous termination of transfer rights, Congress protected the interests of those specific types of beneficiaries it chose to favor rather than permitting states to choose which types of beneficiaries to privilege under state laws of intestate succession or state domestic relations law. The 1976 Copyright Act was not passed in haste. Congress received reports, held hearings, and debated what ultimately became the 1976 Copyright Act over a period of about twenty-years. ${ }^{137}$ The 1976 Copyright Act as a whole represents. a comprehensive negotiated legislative regime that balances the rights of the public to have access to and to use copyrighted works, the incentive rights of authors to control the use of and to profit from the work, and the rights of others that Congress elected to benefit through provisions of the Copyright Act. Therefore the Rodrigue II court erroneously drew the wrong

133 See In re Estate of Kessler, 203 N.E.2d 221, 222-23 (Ohio 1964); Kingma, supra note 132 , at $8 \mathrm{I}-83$.

134 Kingma, supra note 132 , at 83 .

135 Rodrigue II, 218 F.3d 432, 44I (5th Cir. 2000).

I36 See Goldstein, supra note 2 I, $\$$ 5.1.5, 5:19 n.68 (Supp. 2007). Although industry representatives lobbied for a federal copyright foreclosure scheme, Congress found that the benefits from such a system would have limited application and would not justify creating such a complex statutory and regulatory regime. Id.

137 See, e.g., Mark B. Radefeld, Note, The Medium is the Message: Copyright Law Confronts the Information Age in New York Times v. Tasini, 36 AKron L. Rev. 545, 547 n. I I (2003). 
conclusion from Congress's permitting state testamentary and intestate succession laws to govern the transfer of a deceased author's present, but not future, interest in a copyright. Rather the better interpretation of this instance of Congressional acquiescence to state testamentary and intestate succession law is that it is merely a narrow exception to Congress's general intent to displace state laws in the area of copyright. In sum, the court's reliance on Congress's deference to states in the limited area of intestate succession of copyrights is another example of its myopic reasoning.

\section{g. Copyright Economic Incentives}

Seventh, the Rodrigue II court was in error to second-guess Congress's determination as to the quantitative importance of the Copyright Act's economic incentives to promote the progress of science and the useful arts. The author-spouse contended that by creating a community property entitlement, the author would have less incentive to create new works or exploit existing works. In its opinion, the Rodrigue II court did not contend with a long line of United States Supreme Court precedent that "encouragement of individual effort by personal gain is the best way to advance public welfare through the talents of authors and inventors . . ." 138 Rather, the Rodrigue II court held that there was still enough incentive for the author-spouse to continue to exploit existing works or create new ones even after the division of the copyright's property rights according to Louisiana law:

[W] decline to assume globally that the commercial and economic interests of spouses during marriage are so at odds that one spouse would be disinclined to create copyrightable works merely because the economic benefits of his endeavors would inure to the benefit of their community rather than to his separate estate. As for a former spouse's lack of incentive following divorce, we perceive the presence of the proverbial stick and carrot. To mix metaphors, the carrot is the half-a-loaf incentive of the author to exploit pre-divorce copyrights to the best of his ability rather than shelve them and receive no benefit whatsoever; the stick is exemplified by the provision of the Louisiana Civil Code that specifies an affirmative duty "to

138 Mazer v. Stein, 347 U.S. 201 , 2 I 9 (1954); see also Eldred v. Ashcroft, 537 U.S. 186, 219 (2003) ("'By establishing a marketable right to the use of one's expression, copyright supplies the economic incentive to create and disseminate ideas.") (quoting Harper \& Row, Publ'rs, v. Nation Enters., 47 I U.S. 539, $55^{8}$ (1985)); Sony Corp. v. Universal City Studios, Inc., 464 U.S. 417,477 ( 1984 ) ("Copyright is based on the belief that by granting authors the exclusive rights to reproduce their works, they are given an incentive to create, and that encouragement of individual effort by personal gain is the best way to advance public welfare through the talents of authors and inventors in Science and the useful Arts. ... The monopoly created by copyright thus rewards the individual author in order to benefit the public.") (citations omitted) (internal quotation marks omitted); Twentieth Century Music Corp. v. Aiken, 422 U.S. I 5 I, I 56 (1975). 
manage prudently" former community property that remains under one spouse's exclusive control. Indeed, that article imposes a higher duty on a spouse managing former community property than the Code otherwise imposes on that same spouse during the marriage or on a third party co-owner who is not a former spouse. ${ }^{139}$

Under the above understanding of carrots and sticks, the Rodrigue II court took the liberty of halving the value of the copyright to the author, thus decreasing the economic incentive to exploit the existing work or to produce new derivative works. ${ }^{140}$ The economic incentive undergirding copyright law aims to motivate the author-whether it is too much, too little, or just right is a policy determination that is constitutionally vested in Congress and not in the federal courts. ${ }^{141}$ In Eldred $v$. Ashcroft, admittedly a post-Rodrigue case, the United States Supreme Court deferred to a Congressional determination that an increase in value of the copyright to the author from $99.4 \%$ of a perpetual copyright term to $99.8 \%$ of perpetual copyright term was a policy judgment best left to Congress. ${ }^{142}$

\section{h. Rights of Non-Author-Spouse as Beneficial Owner}

Eighth, the Rodrigue $I I$ court failed to consider whether by dividing the royalties to the copyright, it granted the non-author spouse an independent right to sue for copyright infringement as a beneficial owner of the copyright. ${ }^{143}$ Granting standing to the non-author spouse to sue for copyright infringement would be a severe limitation on the right of the author-spouse to manage the copyrights and may affect the value of the copyrighted works. Additionally, this result would "impede Congress's paramount goal in revising the 1976 Act of enhancing predictability and certainty of copyright ownership." 144

\section{i. New Quasi-Fiduciary Management Duty on Author-Spouse}

Ninth and finally, the Rodrigue II court improperly imposed a new duty, totally absent in copyright jurisprudence, on the author-spouse to manage and to exploit the disputed works, notwithstanding that one of the rights of

\footnotetext{
139 Rodrigue II, 218 F.3d at 442 (footnotes omitted).

140 See id. at $442-43$.

141 See Eldred, 537 U.S. at 207 n.15.

142 Id. at 209 n.16.

143 See 17 U.S.C. \$ 501 (b) (2006); Moran v. London Records, Ltd., 827 F.2d I 80, 183 (7th Cir. 1987) (" $[\mathrm{A}]$ fiduciary relationship arose between the parties, and the assignor became a beneficial owner of the copyright with standing to sue infringers should the assignee fail to do so.") (citations omitted) (internal quotations marks omitted); 6 PATRY ON CoPYRIGHT, supra note $36, \S 21: 4$.
}

144 Cmty. for Creative Non-Violence v. Reid, 490 U.S. 730, 749 (1989). 
copyright ownership is the right not to license or to use the work. ${ }^{145}$ Even in the relationship between joint authors who are also co-owners, Congress did not impose a duty to manage the copyright prudently; rather, Congress merely imposed a duty of accounting for any profits or royalties from the exploitation of the work. ${ }^{146}$

\section{j. Summary}

In sum, the Rodrigue II court had a myopic view of the mischief caused by its simultaneous sui generis interpretation of and lack of deference to Louisiana state law. Further, the Court did not fully comprehend the implications that its holding. may have on federal copyright law and policy. If state or other federal courts adopt the analysis of Rodrigue II, the snowball effect could create perverse state-law-level copyright incentives depending on where the author is domiciled, where the spouse chooses to file for divorce, or the state divorce court's choice of which state's substantive law to apply to disputed property. Fortunately, because the opinion was tied very specifically to its interpretation of Louisiana law, it may be weak precedent in future cases in other states.

\section{Marital Rights in a Copyright Asset Created During Marriage}

Having set the stage with a critical analysis of the seminal cases of Worth and Rodrigue, this section will treat the broad question of whether state community property laws (or other state laws allocating property rights at the dissolution of a relationship) conflict with the ownership provisions of the Copyright Act. Under the Supremacy Clause, state laws that conflict with either the Constitution or federal laws are preempted. ${ }^{147}$ Federal preemption analysis generally falls under the rubric of express preemption, conflict preemption, or field preemption. ${ }^{148}$ Although these three forms of preemption are stated as categories, they are quite permeable and indeterminate in practice and application.

I45 See Rodrigue II, 2 8 F.3d 432, 442 (5th Cir. 2000).

I46 See Thomson v. Larson, 147 F.3d 195, 199 (2d Cir. 1998) (citation omitted).

147 Historically, the Supreme Court has consistently held "that state regulation of intellectual property must yield to the extent that it clashes with the balance struck by Congress in [federal] patent laws." Bonito Boats, Inc. v. Thunder Craft Boats, Inc., 489 U.S. 141, 152 ( 1989 ). For other examples, see Compco Corp. v. Day-Brite Lighting, Inc. (376 U.S. 234 (1964)) and Sears, Roebuck \& Co. v. Stiffel Co. (376 U.S. 225 (1964)), where the Supreme Court held in both cases (decided on the same day) that the Illinois unfair competition law was preempted by federal patent laws.

148 Michigan Canners \& Freezers Ass'n, v. Agric. Mktg. \& Bargaining Bd., 467 U.S. 46I, 469 (1984); Stephen A. Gardbaum, The Nature of Preemption, 79 CoRnell L. Rev. 767, 808 (1994); see also Freightliner Corp. v. Myrick, 5 I 4 U.S. 280, 287 (1995). 
Congress may expressly preempt state laws via statute, ${ }^{149}$ but despite the absence of such an express statutory command, a court may still find a state law preempted if it determines that the state law conflicts with federal law or finds that Congress intended federal law to occupy the field and to displace all state regulation. ${ }^{150}$ In the case of conflict or field preemption, state law is preempted if it is impossible to comply with both state and federal law or if "[the challenged state law] stands as an obstacle to the accomplishment and execution of the full purposes and objectives of Congress." ${ }^{151}$ If the putative conflict is an area that is historically committed to the state regulation, then federal courts will not find state law preempted unless "[it] was the clear and manifest purpose of Congress [to preempt state regulation]." As a rule of statutory construction, if there is more than one plausible interpretation of the statute, then courts should ordinarily prefer the interpretation that avoids preemption. ${ }^{152}$

In the special case of a conflict between federal law and state familyproperty law, the conflict must "do 'major damage' to 'clear and substantial' federal interests before the Supremacy Clause will demand that state law be overridden." 153 While the preemption test as articulated by the Court is a high bar, especially when the conflict is between federal law and state family-property law, it is by no means an insurmountable standard. ${ }^{154}$ Despite the U.S. Supreme Court's rhetorically high standard of review and statement of deference to state courts and state laws in domestic relations matters, in almost all the recent community property cases that the Court has considered, it has found that the challenged state laws were preempted. ${ }^{155}$ This history may suggests that in practice, the Court actually gives little more than standard deference to state laws governing questions of family property-law in its conflict preemption analyses. ${ }^{156}$

149 E.g., Altria Group, Inc. v. Good, 555 U.S. 70, 76-78 (2008).

I50 Crosby v. Nat'l Foreign Trade Council, 530 U.S. 363, 372-73 (2000).

15I Id. at 373 (alteration in original) (citation omitted) (internal quotation marks omitted).

I52 Altria, 555 U.S. at 77.

I 53 Hisquierdo v. Hisquierdo, 439 U.S. 572, 58I (1979) (quoting United States v. Yazell, 382 U.S. 341,352 (1966)).

154 See Hisquierdo, 439 U.S. at 582 ("[O]n at least four prior occasions this Court has found it necessary to forestall such an injury to federal rights by state law based on community property concepts."). Hisquierdo became the fifth such case, id. at 591; Ridgway v. Ridgway, 454 U.S. 46, 54-55, 60 ( $198 \mathrm{I}$ ), the sixth case; and Egelhoff v. Egelhoff $e x \mathrm{rel}$. Breiner, 532 U.S. 14I, I5 I (200I), the seventh case. Earlier Supreme Court cases also support this point. See, e.g., Yiatchos v. Yiatchos, 376 U.S. 306, 312-13 (1964); Wissner v. Wissner, 338 U.S. 655, 661 (1950). But see Rose v. Rose, 48 I U.S.619, 636 (1987) (holding that Tennessee statute pursuant to which veteran was ordered by state divorce court to pay child support from his veterans' disability benefits was not preempted by federal law); Free v. Bland, 369 U.S. 663,670 (1962).

I55 See, e.g., Egelhoff v. Egelhoff ex. rel. Breiner, 532 U.S. I 41 (2001).

I 56 See, e.g., id. at 156-6r (Breyer, J., dissenting); McCarty v. McCarty, 453 U.S. 2 r 0, 236 (198I) (Rehnquist, J., dissenting); Hisquierdo, 439 U.S. at 59I (Stewart, J., dissenting); see also Ciolino, supra note 87 , at $636 \&$ n.26. 
1. Article I, Section 8, Clause 8 Preemption.-Any action by a state defining authorship, co-ownership, or allocating either the $\S 106$ copyrights or the economic rights of a copyright owner may conflict with the Copyright and Patent Clause in the United States Constitution. Article I, section 8, clause 8 of the United States Constitution grants Congress the power to "promote the Progress of Science and useful Arts, by securing for limited Times to Authors and Inventors the exclusive Right to their respective Writings and Discoveries[.]"157 This grant of power appears to be a limited grant of authority to Congress to vest the copyright in authors alone (and not others such as spouses or employers). ${ }^{158}$ "Author" is a term of art under copyright law. ${ }^{159}$ The Constitution does not define the term "author" nor has Congress. The U.S. Supreme Court stated that "[a]s a general rule, the author is ... the person who translates an idea into a fixed, tangible expression[.]" 160 Though courts have considered this interpretation of the Copyright Clause, they have squarely avoided the issue of whether Congress could vest authorship in some entity other than the natural person who engaged in the creative work. ${ }^{161}$

157 U.S. CoNST. art. I, § 8, cl. 8.

158 See I-i Nimmer \& Nimmer, supra note 33, $\$$ I.o6; Patry on Copyright, supra note 36 , $\S 3: 19$. The work-for-hire doctrine that vests the copyright to a work created by an employee for the employer within the scope of that employee's employment in the employer as the legal author is based on a series of legal fictions and tenuous assumptions by Congress. NimMER supra, \& r.06[C]; William Patry, Copyright and Community Property: The Question of Preemption, 28 Bull. Copyright Soc'y 237, 267 (1980). Accordingly, it is not clear that Congress may constitutionally involuntarily transfer a copyright from an author, much less whether a state court may do so pursuant to state family-property law. See id. However, a very narrow literal interpretation of the work-for-hire doctrine may escape this purported constitutional infirmity. See Hays v. Sony Corp., 847 F.2d 4I2, 4I 7 (7th Cir. 1988) ("A possible textual handle may be found in the words of section $201(\mathrm{~b}), \ldots$ which appear to require not only that the work be a work for hire but that it have been prepared for the employer ...."), abrogated on other grounds by Cooter \& Gell v. Hartmarx Corp., 496 U.S. 384, 406, 409 ( 1990$)$.

159 See Feist Publ'ns, Inc. v. Rural Tel. Serv. Co., 499 U.S. 340, 346 (199 I); Burrow-Giles Lithographic Co. v. Sarony, I I I U.S. 53, 57-58 ( 1884 ) ("An author in that sense is "he to whom anything owes its origin; originator; maker; one who completes a work of science or literature.").

160 Cmty. for Creative Non-Violence v. Reid, 490 U.S. 730, 737 (1989); see Feist Publ'ns, 499 U.S. at 345. An author is "'to whom anything owes its origin; originator; maker." Feist Publ'ns, 499 U.S. at 346 (quoting Burrow-Giles, I I I U.S. at 58); L. Batlin \& Son, Inc. v. Snyder, 536 F.2d 486, 490 (2d Cir. 1976) (en banc) ("Originality means that the work owes its creation to the author ...."); 1-2 NiMMER ON COPYRIGHT, supra note $37, \$ 2.0$ I ("[B] ecause an author is 'the beginner ... or first mover of anything ... creator, originator,' it follows that a work is not the product of an author unless the work is original.") (footnotes omitted) (citations omitted).

16r See, e.g., Childress v. Taylor, 945 F.2d 500, 506-07 \& n.5 (2d Cir. 1991); Scherr v. Universal Match Corp., 417 F.2d 497, 502 (2d Cir. 1969) (Friendly, J., dissenting); Schmid Bros. v. W. Goebel Porzellanfabrik KG., 589 F. Supp. 497, 503 (E.D.N.Y. 1984) ("The Constitution in Article $\mathrm{I}, \S 8$, clause 8 , authorizes grants to 'authors' and not to their employers. An author may, of course, assign to her employer her rights to exploit the work. But an employer, to be regarded as an 'author,' must presumably make some significant contribution to the work. The 
In Worth, the author-spouse claimed that because federal law vests the copyright solely in the author and state community property laws provide for an equal interest in the copyright, state law is in conflict with federal law and thus preempted. ${ }^{162}$ The Worth court rejected as constitutionally mandated a limited definition of author as creator-originator, holding that '[t]he term 'author,' within the constitutional text, may be construed to include the author's spouse under the principles of co-ownership or transferred ownership we have discussed." 163 While copyright law does not clearly establish the full range of potential authorship, at a bare minimum each individual purporting to be an author must contribute something original to the work. ${ }^{164}$ This may even be a constitutional requirement. ${ }^{165}$ More stringently, statutory copyright law "requires [an author to make] more than a minimal creative or original contribution to the work." 166 By illustration, in the context of the creation of joint-works, courts have rejected joint-authorship when the contribution of a putative joint-author did not include original expression. ${ }^{167}$ Further, Congress has the limited power to grant to authors a body of undefined exclusive rights for a period of time. ${ }^{168} \mathrm{It}$ is not as self-evident as the Worth court's succinct holding intimates that either the constitutional or statutory use of the term "author" (or even co-ownership) without more may be expanded to include a spouse who makes no original contribution to the copyrighted work. ${ }^{169}$

In Rodrigue II, the court did not divide the non-economic attributes of authorship or even the limited $\S 106$ grant of exclusive copyrights. Rather, the Fifth Circuit relied on a sui generis Louisiana state law to convert a federally-created property right in the $\S 106$ copyright to a state law body of severable property rights. The Court then permitted the author to retain ownership and management of the $\S 106$ bundle of exclusive rights while dividing under state law any economic rights to the copyright's exploitation. ${ }^{170}$ The constitutional grant of power to Congress

Constitution could hardly have contemplated that mere employment was enough.") (citation omitted).

I62 In re Marriage of Worth, 24I Cal. Rptr. I35, 139 (Cal. Ct. App. 1987).

163 Id. at 139 n.5.

164 See Feist Publ'ns, 499 U.S. at 346.

I65 See id; Burrow-Giles, i I I U.S. at 57-58; NimmER \& Nimmer, supra note 33, \& 1.06.

166 Aalmuhammed v. Lee, 202 F.3d I 227, 1233 (9th Cir. 2000) (suggesting a higher originality standard for authorship as opposed to that required for copyright to merely subsist).

I67 See Childress v. Taylor, 945 F.2d 500, 507 (2d Cir. I99 I). But see Gaiman v. McFarlane, 360 F.3d 644, 658-59 (7th Cir. 2004) ("The decisions that say, rightly in the generality of cases, that each contributor to a joint work must make a contribution that if it stood alone would be copyrightable weren't thinking of the case in which it couldn't stand alone because of the nature of the particular creative process that had produced it.").

I68 See Nimmer \& Nimmer, supra note 33, § 1.05[A][I] \& § I.06[A].

I69 See infra Part III.F.

I 70 See Nimmer \& Nimmer, supra note $33, \S 6 A .05$. 
to enact copyright laws presupposes that the economic rights would accompany whatever limited copyright rights that Congress chose to grant to authors. ${ }^{171}$ A limited period of authorial copyright exclusivity without the accompanying economic rights elevates form over substance and would disserve the copyright's utilitarian incentive to the author to promote the creation and the dissemination of knowledge. ${ }^{172}$ An author's copyrights and the associated economic rights are constitutionally (and statutorily) vested in the author as an individual, and state laws that involuntarily transfer them from the author are constitutionally suspect. ${ }^{173}$

2. Express Preemption (17 U.S.C. § 301).-Section 301 is the express preemption section of the 1976 Copyright Act. Section 301 has two express copyright preemption provisions: $\S 301$ (a) ard $\S 301(\mathrm{f}) .{ }^{174}$ Section 301 (a) is the general preemption provision of the Copyright Act precluding states from granting rights that are the equivalent of $\S 106$ copyrights in fixed works of authorship. ${ }^{175}$ Section 301 (f) preempts state laws that grant rights equivalent to those granted in 17 U.S.C. $\S 106 \mathrm{~A}$, the Visual Artists Rights Act of 1990 (VARA). ${ }^{176}$ This section will ultimately conclude that both provisions of $\S 301$ preempt state community property law.

\section{a. Section 301(a) (17 U.S.C. $§ 106$ Preemption)}

Section 301(a) is a broad express preemption provision in the Copyright Act. ${ }^{177}$ Section 301 (a) by its own terms displaces

all legal or equitable rights that are equivalent to any of the exclusive rights within the general scope of copyright as specified by section 106 in works of authorship that are fixed in a tangible medium of expression and come within the subject

17 I Nevins, Jr., supra note 87, at 519.

172 See generally Steven Hetcher, Desire Without Hierarchy: The Behavioral Economics of Copyright Incentives, 48 U. Louisville L. REv. 817 (2010) (discussing the economic approach to understanding incentives and creativity in copyright).

173 See Bd. of Regents v. Roth, 408 U.S. 564, 577 (1972) ("To have a property interest . . a person clearly must have more than an abstract need or desire for it. . . He must, instead, have a legitimate claim of entitlement to it."); Patterson v. Portch, 853 F.2d 1399, 1405 (7th Cir. 1988) ("[P]roperty under the due process clause is any interest to which a government has given someone an entitlement.").

174 See 17 U.S.C. $\$ 301$ (2006).

I 75 Id $\$ 30$ I (a).

I 76 See infra Part III.D.2.b.

177 See Cmty. for Creative Non-Violence v. Reid, 490 U.S. 730, 740 ( 1989) ("Establishment of a federal rule of agency[] . . . is particularly appropriate here given the Act's express objective of creating national, uniform copyright law by broadly pre-empting state statutory and common-law copyright regulation."); see also United States ex rel. Berge v. Bd. of Trustees of the Univ. of Ala., I04 F.3d 1453, I463 (4th Cir. 1997) ("[T]he shadow actually cast by the [Copyright] Act's preemption is notably broader than the wing of its protection."). 
matter of copyright as specified by sections 102 and 103[]$\ldots$. [N]o person is entitled to any such-right or equivalent right in any such work under the common law or statutes of any State. ${ }^{178}$

Section 301(b) provides a limited exception for state law-based rights and remedies that are not within the subject matter of federal copyright (as defined by $\S 102$ and $\S 103$ ) or that are not equivalent to the author's rights under $\S 106 .{ }^{179}$ Unsurprisingly, $\S 301$ presents the specter of federal preemption of state laws allocating copyrights in marital dissolution proceedings.

The Worth court gave short shrift to the author-spouse's contentions that $\S 301$ (a) preempted California's community property laws that allegedly transmuted copyright ownership from the author-spouse into co-ownership with the non-author spouse. ${ }^{180}$ The Worth court found that $\S 301$ (a) only displaced state statutory and common law copyright laws and that other state laws such as those relating to the ownership and division of marital property were not preempted. ${ }^{181}$ Yet two years later in Community for Creative Non-Violence v. Reid, the United States Supreme Court would rely on $\S 301$ (a)'s sweeping preemption of state laws and regulation to justify rejecting individual state law definitions of "employee" and announcing instead a federal common law definition derived from the Restatement (Second) of Agency. ${ }^{182}$ As construed by the courts, the sweep of $\S 301$ (a) may be broader than its literal language. ${ }^{183}$ The Worth court's analysis is at best perfunctory, at worst merely conclusory, and in any case, without significant bearing on copyright preemption analysis. Therefore, it does not merit further discussion.

Section 301(a) conflict-preemption contentions did not fare better in the appeal in Rodrigue II. The court did not completely analyze possible conflicts between $\S 301$ (a) and Louisiana state community property law. ${ }^{184}$ For example, the court stated with approval that Louisiana law imposed an obligation on the author-spouse to manage the fructus of the copyrighted property prudently. ${ }^{185}$ This presupposes a duty to at least attempt to exploit the copyrighted work, if not the more onerous burden of creating new


ist does not work well under compulsion, and the court might find it difficult to pass judgment upon the performance rendered."') (citation omitted).

I 84 See Rodrigue I, 55 F. Supp. 2d 534, 540-4 I (E.D. La. 1999), rev'd on other grounds, 218 F.3d 432, 439-40 (5th Cir. 2000) (rejecting \& 301 (a) preemption).

I 85 Rodrigue II, 218 F.3d at 442-43. 
derivative works. ${ }^{186}$ Yet, this state-imposed obligation may grant a right that is in direct conflict with the author's rights under $\S 106$. Section 106 includes the negative right not to publish, license or to otherwise exploit the work $^{187}$ and the positive right to choose when and how to introduce the work to the public. ${ }^{188}$ Further, any obligations that portend to force an author to create new works raise serious First Amendment concerns regarding compelled speech, ${ }^{189}$ as well as involuntary servitude concerns. ${ }^{190}$.

\section{b. Section 301(f) (17 U.S.C. $§ 106$ A Preemption)}

Although Worth and Rodrigue addressed the division of $\S 106$ economic rights with the non-author spouse, ${ }^{191}$ courts have not yet considered an author-spouse's limited moral rights under the Visual Artists Rights Act (VARA), 17 U.S.C. § 106A. ${ }^{192}$ "VARA was designed to protect the moral rights of artists in their works. Moral rights protect an artist's interest in the proper use of the artist's name and in maintaining the physical integrity of the artist's work." ${ }^{193}$ The exercise of the $\S 106$ economic rights, if conveyed

I 86 See Ciolino, supra note 87, at 632 ("Perhaps most surprisingly, a non-author spouse now may be able to compel an author-spouse to, among other things, create and distribute new works based on community copyrights if a 'prudent administrator' would do so."); $q f$. Simon \& Schuster, Inc. v. Members of the N.Y. State Crime Victims Bd., 502 U.S. 105, I 15-16 (1991) ("A statute is presumptively inconsistent with the First Amendment if it imposes a financial burden on speakers because of the content of their speech.").

187 See, e.g., Harper \& Row, Publ'rs, Inc. v. Nation Enters., 47 I U.S. 539, 564 ( I985) (“The right of first publication encompasses not only the choice whether to publish at all, but also the choices of when, where, and in what form first to publish a work."); Fox Film Corp. v. Doyal, 286 U.S. 123, 127 (1932); Orson, Inc. v. Miramax Film Corp.; 189 F.3d 377, 385 (3d Cir. 1999) (en banc) (citing Stewart v. Abend, 495 U.S. 207, 228-29 (1990)); Salinger v. Random House, Inc., 81 1 F.2d 90, 99 (2d Cir. 1987).

I 88 Harper \& Row, 47 I U.S. at 564.

I 89 See Wooley v. Maynard, 430 U.S. 705, 714 (1977) ("[T]he right of freedom of thought protected by the First Amendment against state action includes both the right to speak freely and the right to refrain from speaking at all.").

190 See, e.g., Barndt v. County of L.A., 259 Cal. Rptr. 372, 403-04 (Cal. Ct. App. 1989) ("An artist does not work well under compulsion, and the court might find it difficult to pass judgment upon the performance rendered." (quoting 5A ARTHur LinTon Corbin, Corbin on Contracts § 1204 ( 1964))); Cagle v. Hybner, No. M2006-02073-COA-R3-CV, 2008 WL 2649643, at *20 (Tenn. Ct. App. July 3, 2008).

I9I Rodrigue II, 218 F.3d 432, 443 (5th Cir. 2000); In re Marriage of Worth, 24I Cal. Rptr. 135,140 (Cal. Ct. App. 1987). The Worth case was decided in 1987 , and VARA was not enacted until 1990. See Visual Artists Rights Act of 1990, Pub. L. 101-650, Title VI, §603(a), I04 Stat. 5128 ( 1990$)$.

192 The copyrighted works in Worth (books) were not eligible for VARA protection. See 17 U.S.C. $\$ 101$ (2006) (defining a "work of visual art"). The dispured paintings in the Rodrigue line of cases appear to be VARA-protected works. See id.

I 93 Teter v. Glass Onion, Inc., 723 F. Supp. 2 d I 138, 1158 (W.D. Mo. 2010) (citing Berrios Nogueras v. Home Depot, $33^{\circ}$ F. Supp. 2d 48, 50 (D.P.R. 2004)); see also Carter v. HelmsleySpear, Inc., 7 I F.3d 77, 8I-83 (2d Cir. 1995). VARA protects only a "work of visual art," which 
through state community property law, may be inconsistent with the exercise of the author's moral rights. Of note, the economic rights under $\S 106$ are legally distinct from the moral rights (or VARA rights) under $\S 106 \mathrm{~A} .{ }^{194}$ The author of a work of visual art enjoys rights that are similar, but not strictly equivalent, to the European or civil law concepts of moral rights. ${ }^{195}$ The author has the right of attribution and the right to prevent the artist's name from being associated with a work that the artist did not create. ${ }^{196}$ Under VARA, the author also possesses the right to prevent the use of the author's name when the author's work is distorted or mutilated, if use of the author's name would be prejudicial to the author's honor or reputation. ${ }^{197}$ Furthermore, the author also enjoys the right to prevent an intentional distortion or mutilation of a work that would be prejudicial to the author's honor or reputation as well as the right to "prevent any destruction of a work of recognized stature, [or an] intentional or grossly negligent destruction of that work ...."198

Section $301(f)(1)$ preempts state laws that purport to grant legal rights that are the equivalent of VARA. ${ }^{199}$ Any moral rights within the subject matter of VARA are governed exclusively by VARA, and thus "no person is entitled to any such right or equivalent right in any work of visual art under

is defined as (1) a painting, drawing, print, or sculpture, existing in a single copy, in a limited
cdition of 200 copies or fewer that are signed and consecutively numbered by
the author, or, in the case of a sculpture, in multiple cast, carved, or fabricated
sculptures of 200 or fewer that are consecutively numbered by the author
and bear the signature or other identifying mark of the author; or (2) a still
photographic image produced for exhibition purposes only, existing in a single
copy that is signed by the author, or in a limited edition of 200 copies or fewer
that are signed and consecutively numbered by the author.

17 U.S.C. § 101 (2006).

194 See Berrios Nogueras, 330 F. Supp. 2d at 50.

I95 See Carter, 71 F.3d at 81-83 (discussing VARA rights and civil law counterparts); Llewellyn Joseph Gibbons, Visual Artists Rights Act ("VARA") and the Protection of Digital Works of "Photographic" Art, I I N.C. J.L. \& TECH. 53 I, 533 (20 Io); see also H.R. REP. No. IO I-5I4, at 14-15 (1990), reprinted in 1990 U.S.C.C.A.N. 6924-25. VARA uses the term "author" rather than artist so, following VARA's nomenclature, this article also uses author to describe works created by individuals more often and accurately called artists in the vernacular.

I96 17 U.S.C. $\S$ I06A(a) (2006). VARA excludes "(A)(i) any poster, map, globe, chart, technical drawing, diagram, model, applied art, motion picture or other audiovisual work, book, magazine, newspaper, periodical, data base, electronic information service, electronic publication, or similar publication; (ii) any merchandising item or advertising, promotional, descriptive, covering, or packaging material or container; ... (B) any work made for hire; or (C) any work not subject to copyright protection under this title.” 17 U.S.C. $\& 101$ (2006) ("Definitions").

19717 U.S.C. § Io6A(a)(2); Berrios Nogueras, 330 F. Supp. 2d at 50.

$198 \& 106 \mathrm{~A}(\mathrm{a})(3)$.

19917 U.S.C. $\S 301(f)(\mathrm{I})$ (2006); Chen v. Cayman Arts, Inc., No. 10-80236-CIV., 201 I WL 782279, at *6 (S.D. Fla. 201 I). 
the common law or statutes of any State." ${ }^{200}$ Yet common law and statutory remedies are not otherwise limited with respect to "activities violating legal or equitable rights that are not equivalent to any of the rights conferred by [VARA] with respect to works of visual art[.]"201 VARA governs not only an author's rights of attribution and integrity in the work ${ }^{202}$ but also the transfer and waiver of those moral rights. ${ }^{203}$.

VARA was not enacted until 1990,three years after the Court's decision in In re Marriage of Worth. Moreover, even had the statute been in existence, the copyrighted literary works in In re Marriage of Worth would not have been eligible for protection as "works of visual art." ${ }^{204}$. Although VARA was in existence at the time Rodrigue was decided, one may only speculate on the application of VARA to its facts, for the parties did not raise $\$ 301$ (f) preemption, and the court.did not.address the issue sua sponte in its opinion. ${ }^{205}$ Rodrigue provides an interesting real world fact pattern on which to examine the application of VARA and $\S .301(f)$ preemption in the intersection of state domestic relations law and federal copyright law. The facts provided in the district court's opinion are consistent with a determination that the author-spouse's paintings would have been VARA protected works. ${ }^{206}$ The federal court granted the non-author spouse an equal share of the author's economic rights without addressing the question of moral rights in the copyrighted works. ${ }^{207}$ Further, the Rodrigue II court in dicta, citing state law, instructed the author-spouse to manage the $\$ 106$ economic rights prudently. ${ }^{208}$ One may infer that this instruction applied not only to the economic rights relating to the works made during his marriage but also to the economic rights to any subsequent post-divorce derivative works. ${ }^{209}$ The highest and best use of a copyright for income maximization

20017 U.S.C. $\$ 301(f)(1)$.

$201 \S 30 I(f)(2)$.

202 I 7 U.S.C. $\S$ I06A(a).

$203 \S 106 \mathrm{~A}(\mathrm{e})$.

204 Compare In re Marriage of Worth, 241 Cal. Rptr. at 138 (copyright of a literary work), with 17 U.S.C. $\S$ IOI (2006) (defining "work of visual art" as a painting, drawing, print, sculpture or photographic image and excluding books, magazines, newspapers, and periodicals).

205 See Rodrigue v. Rodrigue (Rodrigue $I I$ ), 218 F.3d 432 (5th Cir. 2000); Original Brief on Behalf of Defendant/Counterclaimant-Appellant, Veronica Hidalgo Rodrigue, Rodrigue II, 218 F.3d 432 (No. 99-30334), 1999 WL 33618615; Reply Brief on Behalf of Rodrigue, Rodrigue $I I, 218$ F.3d 432 (No. 99-30334) I999 WL 336186 I6; Opposition of Defendant/Counterclaimant-Appellant, Veronica Hidalgo Rodrigue to Petition for Rehearing en Banc, Rodrigue II, 2 I 8 F.3d 432 (No. 99-30334), 2000 WL 33991195.

206 See Rodrigue I, 55 F. Supp. 2d 534, 536 (E.D. La. 1999), rev'd on other grounds, Rodrigue $I I, 218$ F.3d 432, 439 (5th Cir. 2000); see also Kundawala, supra note 122, at 165-66. Compare Rodrigue I, 55 F. Supp. 2d at 536, with 17 U.S.C. \$ IoI (definition of a "work of visual art").

207 Rodrigue $I I, 2$ I 8 F.3d at 443.

$208 \mathrm{Id}$.

209 Id. (citing LA. Civ. CODE ANN. art. 2369.3 (2010)). The Louisiana standard for evaluat- 
is not necessarily consistent with its highest and best use for maintaining or promoting the artist's creative integrity. Further, short-term economic uses of a work may benefit the divorced spouse but injure both the author's longer-term development as an artist and longer-term economic interests.

While $\S 106$ economic rights are defeasible, $\S 106 \mathrm{~A}$ moral rights vest solely in the author. ${ }^{210}$ Unlike economic rights, moral rights may be waived (in writing) but not transferred or assigned, even (arguendo) by operation of state law. ${ }^{21}$ The potential conflicts between the prudent profit-maximizing exploitation of the economic rights and the moral rights of the author may be made clearer using two examples. First, assuming that works with the artist's name and signature are more valuable than works without them, the $\S 106$ economic rights rationale under Rodrigue II would require the artist to accept attribution and sign these works under some theory of the author's duty to manage the copyright estate prudently. However, if for some reason the artist thought that the work was flawed or otherwise was prejudicial to the artist's reputation, under $\S 106 A$ the author could decline to sign or attribute the work. ${ }^{212} \mathrm{~A}$ prudent author may desire to sell or dispose of a second rate or flawed work without placing her name on it. These works would not have the same economic value as signed original works protected under VARA. Thus; by placing the use and management of the work in the hands of the author and overlaying the division of the interest in the economic benefits of the copyright with a fiduciary-like duty imposed on the author-manager-spouse, the non-author spouse's beneficial economic interests may conflict with the author's free exercise of $\S 106 \mathrm{~A}$ moral rights that are by statute vested solely in the author.

As a second example, a prudent economic use of a flawed bronze statue may be to sell it for its scrap metal value, just as a prudent use of another artwork might be to permit it to be divided into smaller units for retail sale. ${ }^{213}$

ing prudent management is not readily clear to one not trained in the civil law (such as the author), but it seems to be interpreted as a failure to act prudently "in a manner consistent with the mode of use of [the] property immediately prior to termination of the [marriage]. [The spouse] is answerable for any damage caused by his fault, default or neglect." See Saacks v. Saacks, 942 So. 2d I I30, I 36 (La. Ct. App. 2006) (quoting art. 2369.3); Katherine Shaw Spaht, Co-Ownership of Former Community Properzy: A Primer on the New Law, 56 LA. L. Rev. 677, 698 \& n.I49 (1996) ("The slight fault is that want of care which a prudent man usually takes of his business."). See generally SPAHT \& MoReno, supra note I 10, \$ 5.22.

2 I0 17 U.S.C. $\$ 106 \mathrm{~A}(\mathrm{~b})$.

2 I I See $\S$ I06A(e). The $\S$ I06A moral rights last for the life of the author. $\S$ I06A(d).

$212 \S 106 \mathrm{~A}(\mathrm{a})(2)$.

2 I3 Cf. Mirage Editions, Inc. v. Albuquerque A.R.T. Co., 856 F.2d 134I, 1342 (9th Cir. 1988) (destroying a book in order to mount images from book onto ceramic tiles for individual retail sale); William M. Landes, What Has the Visual Arts Rights Act of 1990 Accomplished? 10-15 (Univ. of Chi. Law Sch. John M. Olin Law \& Econ., Working Paper No. 123, 2001), available at http:/www.law.uchicago.edu/files/files/123.WL_.VARA_pdf (speculating on whether art may be sometimes more valuable in a smaller units). Christo and JeanneClaude are two artists famous for wrapping buildings, islands, and even the German Reich- 
Most people cannot afford to purchase a recognized Picasso lithograph for $\$ 100,000$, but some may be willing to spend $\$ 100$ for a one-square-inch section of the lithograph in order to be the "owner" of a Picasso. ${ }^{214}$ Under $\S 106$ and the holding of the Rodrigue II court, this desecration of a work of art would be an economically income maximizing exchange under $\S 106$; in other words, a prudent exploitation of the economic rights of the copyright owner. However, in the case of a VARA-protected work, the author clearly has a separate and independent moral right to prevent this mutilation. ${ }^{215}$

Further, the statute grants an author, not a copyright osener; the legal right to protect a VARA work of visual art from "any intentional distortion, mutilation, or other modification of that work which would be prejudicial to his or her honor or reputation[]" or "to prevent any destruction of a work of recognized stature[.]"216 No state court could order an artist to waive his or her moral rights for the economic benefit of the non-author spouse. An order of a court protecting state law allocation of economic rights that comes into conflict with an exercise of the personal moral rights vested solely in the author by Congress would be preempted.

3. 17 U.S.C. \& 201(e) (Involuntary Transfer Preemption).-Section \$ 201(e) should have been given the popular name "the Russians are Coming and the Sky Is Falling Act of 1973."217 Section 201(e) explicitly provides that

[w]hen an individual author's ownership of a copyright, or of any of the exclusive rights under a copyright, has not previously been transferred voluntarily by that individual author, no action by any governmental body or other official or organization purporting to seize, expropriate, transfer, or exercise rights of ownership with respect to the copyright, or any of the exclusive rights under a copyright, shall be given effect under this title, except as provided under title 11 [bankruptcy proceedings]. ${ }^{218}$

stag in fabric and later selling the fabric at the completion of the project to raise funds for future art works. Kirk Johnson, Bureaucracy Meets Art, Delighting Christo, N.Y. Times, July 17 , 2010, http://www.nytimes.com/2010/07/1 7/us/1 7artist.html; Glen Warchol, Christo's Epic Ribbon of Red Tape, Salt Lake Tribune, Apr. 18, 20 I I, http://archive.sltrib.com/printfriendly. php? id $=516281$ 70\&itype $=$ cmsid.

2 I 4 See Landes, supra note 213 , at 10 . As another real-world example, a damaged Gutenberg Bible was dismantled in the I920s and sold by section or by individual page to libraries and collectors. See Pre Reformation Bibles - Gutenberg Bible, The Gruber Rare Books CollecTION AND OTHER RARE BOOKs, http://www.lstc.edu/gruber/pre_ref_bibles/gutenberg.php (last visited Sept. 10, 2012).

215 See 17 U.S.C. \& IO6A (2006); 5 .PATry ON Copyright, supra note 36, § $16: 20$.

216 See $\S 106 \mathrm{~A}(\mathrm{a})(3)(\mathrm{A})-(\mathrm{B})$; Carter v. Helmsley-Spear, Inc., 7 I F.3d 77, 83 (2d Cir. 1995).

217 See generally Films by Jove, Inc. v. Berov, 154 F. Supp. 2d 432, 449 (E.D.N.Y. 2001 ) (describing an interesting exegesis on Soviet era property law and copyright law).

2 I 8 I 7 U.S.C. $\$ 201$ (e) (2006). 
While it was the intent of Congress with $\S 201(\mathrm{e})$ to preclude the U.S. courts from recognizing the appropriation of a copyright by a foreign government, the clear language of $\$ 201$ (e) preempts state laws, including the common law, from involuntarily transferring initial copyright ownership. ${ }^{219}$ In 1973, the then-Union of Soviet Socialist Republics (USSR) joined the Universal Copyright Convention. ${ }^{220}$ Congress feared that dissent Soviet authors would be intimidated into transferring their copyrights, that their copyrights would be expropriated (nationalized), or that their copyrights would be confiscated through some sham judicial process by the USSR. ${ }^{221}$ The government of the USSR would then use its ownership of copyrights to petition U.S. courts to enjoin the publication of dissent works. ${ }^{22}$ There was no evidence that the USSR ever attempted to use whatever putative claim it may have had to the works of its citizens to enforce its rights under copyright law. Besides, the Universal Copyright Convention would not

219 Scott M. Martin \& Peter W. Smith, The Unconstitutionality of State Motion Picture Film Lien Laws (or How Spike Lee Almost Lost It), 39 AM. U. L. REv. 59, 91-92 (1989); see also 3-10 Melville Nimimer \& David Nimmer, Nimmer on Copyright § 10.04 ( I989) ("By its terms Section 201 (e) is not limited to acts by governmental bodies and officials. It includes acts of seizure, etc., by any 'organization' as well. It is, moreover, not limited to such acts by foreign governments, officials, and organizations."); PATRY ON Copyright supra note 36, \$ 4:76 ("Any involuntary transfer should be void under the plain language of section $201(\mathrm{c})$....").

220 Martin \& Smith, supra note 219, at 91-92. American courts (and government) looked on the government of the USSR with (at best) unconcealed skepticism. See Zschernig v. Miller, 389 U.S. 429,436 n. 6 ( 1968 ) ("Russia had no separation of powers, too much control in the hands of the Communist Party, no independent judiciary, confused legislation, unpublished statutes, and unrepealed obsolete statutes."). Before stating its holding of no reciprocity, the court also noted Stalin's crimes, the Beria trial, the doctrine of crime by analogy, Soviet xenophobia, and demonstrations at the American Embassy in Moscow unhindered by the police. The court concluded that a leading Soviet jurist's construction of article 8 of the law enacting the R.S.F.S.R. Civil Code seemed modeled after Humpty Dumpty, who said, "When I use a word * * ", it means just what I choose it to mean-neither more nor less." Id. at 435 n.6 (citing another source).

221 Id. at 91; see I 19 Cong. Rec. S $1359,9387-88$ (daily ed. March 26, 1973) (statement of John McClellan). Senator McClellan considered the USSR's adherence to the Universal Copyright Convention as a stratagem to suppress works "of literature which does not meet with Communist approval." Id. at 9387. In March 1973, Senator McClellan introduced legislation that was the inspiration for section 20I(e) of the 1976 Copyright Act. Martin \& Smith, supra note 219 , at 92 n.185. "That bill provided that any copyright would remain the property of the author ... regardless of any law, decree or other act of a foreign state or nation which purports to divest the author or said other persons of the United States copyright in his work. The same principle also appeared in H.R. 2223, 94th Cong., I st Sess., \$ 104(c) (1975)." Id. (citations omitted) (internal quotation marks omitted); see also Nevins, Jr., supra note 7, at 383-86.

222 Martin \& Smith, supra note 219, at 92. But see Mira T. Sundara Rajan, Copyright and Creative Freedom: A Study of Post-Socialist Law Reform $104-07$ (Routledge 2006) (discussing two examples of the former USSR acting on "behalf" of a Soviet author objecting on French moral rights grounds to a translation and a moral rights claim on behalf of a Soviet composer involving the use of public domain music in a motion picture soundtrack). 
have required U.S. courts to recognize the USSR's appropriation of an author's copyright. ${ }^{223}$

Any attempt at using copyright law to censure the publication of a copyrighted work would raise serious First Amendment questions as well as questions regarding the prudential policies underlying equitable remedies. ${ }^{224}$ When the public interest is involved, courts have broad discretion in granting an injunction or crafting appropriate equitable relief. ${ }^{225}$ The First Amendment values of promoting and protecting free and robust speech coupled with the core constitutional (and statutory) copyright values of promoting the progress of science and the useful arts though the creation and dissemination of copyrighted works would caution against granting an injunction under these circumstances. And, "[w]here an important public interest would be prejudiced; the reasons for denying injunctive relief may be compelling." ${ }^{226}$ Copyright law is not a robust enough tool to censure ideas. Copyright only protects the expression of an idea and not the underlying idea being expressed, so even an injunction would only stop the dissemination of the dissent-authored work and not the ideas contained within the work. If Congress repealed or clarified the scope of $\S 201$ (e), the many preemption problems discussed in this article might be eliminated. ${ }^{227}$ An author's initial legal interest in a copyright could then be reduced to just another species of personal property that could then be disposed of through either a voluntary transfer or an involuntary transfer by operation of state law. However, despite numerous revisions to the Copyright Act, and vituperative criticism by courts and commentators, Congress has demonstrated no inclination to repeal $\$ 201(\mathrm{e})$.

One significant weakness in the Worth court's opinion is that it did not consider $\S 201(\mathrm{e})$ of the Copyright Act when analyzing whether $\S 201$ preempted California's community property laws, at least insofar as these laws purport to enable the conversion of a copyright owned by the authoring spouse into a copyright co-owned with the non-authoring

223 Martin \& Smith, supra note 219 , at 92 \& nn. I 85-86 (citing Nimmer \& Nimmer, supra note $219, \S 10.04$, at 10-41 to $10-42$ ( 1989 ) ("Universal Copyright Convention would not have forced American courts to recognize any Soviet seizure ...."); see also Paul Goldstein, Preempted State Doctrines, Involuntary Transfers and Compulsory Licenses: Testing the Limits of Copynight, 24 UCLA L. Rev. I I07, I I 23-27 (1977); Nimmer \& Nimmer, supra note 2 19, § 10.04.

224 See 17 U.S.C. $\$ 502$ (a) (2006) (stating that a court "may" enjoin infringement); N.Y. Times Co. v. Tasini, 533 U.S. 483, 505 (2001) (citing Campbell v. Acuff-Rose Music, Inc., 510 U.S. 569,578 , n. Io (I 994$)$ ) ("[G]oals of copyright law are not always best served by automatically granting injunctive relief.").

225 Mercoid Corp. v. Mid-Continent Inv. Co., 320 U.S. 66I, 670 (1944).

226 Id. (citations omitted) (internal quotations marks omitted).

227 Alternatively, states could pass laws changing the definition of community property. But see William Patry, Copyright and Community Property: The Question of Preemption, 28 BuLL. COPYRIGHT Soc'y 237, 237 n.3 (1980) (explaining that some states define community property in the state constitution). 
spouse. Surprisingly, the Worth court also did not consider whether the author-spouse's agreement to a stipulated judgment ${ }^{228}$ was sufficient to legally effect a voluntary transfer under $\S 201(\mathrm{e}){ }^{229}$ In other words, the court did not analyze the agreement or determine whether this agreement could have provided an independent ground on which to rest its decision. Commentators and other critics may wish to give the Worth court the benefit of the doubt and speculate that the stipulated judgment was the unstated reason why the court did not opine on the vexatious problems presented by $\S 201(\mathrm{e}){ }^{230}$ In contrast, the $\S 201(\mathrm{e})$ issues were clearly addressed in the Rodrigue district court opinion and raised again on appeal. Therefore, there is no apparent reason why the appeals court in Rodrigue II did not squarely face the troublesome question of the "voluntariness" of the copyright transfer by operation of state law. ${ }^{231}$

Eschewing the first rule of statutory interpretation that courts do not look to the legislative history unless the text of the statute is unclear, the leading commentators rely on the legislative history in order to divine what Congress intended by $\S 201(\mathrm{e}) .{ }^{232}$ "The House Report states that Section 201(e) would not inhibit transfers of ownership pursuant to proceedings in bankruptcy and mortgage foreclosures, because in such cases the author, by his overt conduct in filing in bankruptcy, or hypothecating a copyright, has consented to such a transfer." 233 Allowing "voluntariness" of transfer to be inferred from certain conduct is inconsistent with the requirement of statutory formalities in other provisions of the Copyright Act. For example, under $\S 204$, a transfer of ownership has to be executed in a signed writing, and $\S 101$ defines a transfer of ownership to include a mortgage. ${ }^{234} \mathrm{~A}$ mortgage is a voluntary agreement and under copyright law it is also a voluntary transfer of ownership so that in the case of default, the mortgagor

228 "The parties agree that future royalties from the books . . . listed on the Petition, along with all reprints shall be paid equally to Petitioner and Respondent. . . . The parties agree that the court shall reserve jurisdiction over any issues that may subsequently arise regarding the distinction between a re-edition or complete reworking of any book which is community property." In re Marriage of Worth, 24 I Cal. Rptr. 135, 337 (Cal. Ct. App. 1987).

229 Rodrigue I, 55 F. Supp. 2d 534, 543 (E.D. La. 1999).

230 See Patry supra note 36, \$ 5: 116 \& n.6.50 (citing Siegel v. Warner Bros. Entertainment, Inc., 542 F. Supp. 2d 1098, I $131-32$ (C.D. Cal. 2008)) (stating that consent judgments are voluntary).

231 One may read into the Rodrigue $I I$ opinion that because only the $\S$ I 06 rights were vested in the author, and not the concomitant economic rights, that there was no transfer, and therefore, no reason to discuss whether there was a voluntary transfer under $\$ 20 \mathrm{I}(\mathrm{e})$.

232 See Goldstein, supra note 2 I, § 5.I.6, at.5:2 I; Nimmer \& Nimmer, supra note 33, § 6A.03; PATry supra note $36, \S 5: 116$.

233 NimMER \& NimMER, supra note $219, \$ 10.04$ ( I 989); see also GoldSTEIN, supra note 21 $\S$ 5.1.6, at 5:2 I; PATRY supra note 36, $5: 116$.

234 See 17 U.S.C. \$§ 204, 10 I (2006). See also 17 U.S.C. § I06A(e)(1) (2006) (requiring that a VARA waiver be in writing); Martin v. City of Indianapolis, 192 F.3d 608,614 (7th Cir. 1999). 
could sell the copyright without contravening $\S 201(\mathrm{e}) .{ }^{235}$ Congress later added Chapter 11 bankruptcy proceedings which are now included as an express exception in $\$ 201(\mathrm{e})$. Of note, the bankruptcy estate only consists of works that have already been created or are at least in progress, and not prospective works to be created in the future. ${ }^{236}$ There may be some small subset of transfers by operation of law (other than by marriage) where there is conduct arguably manifesting consent, but there is no writing. Curiously, Congress made no separate or special provision for actions brought by the Internal Revenue Service or for state insolvency proceedings.

Considering that $\S 201(\mathrm{e})$ does not expressly require a writing, commentators contend that any voluntary conduct or course of conduct that is sufficient to demonstrate an intent to transfer a $\$ 106$ copyright is sufficient under $\S 201(e) .{ }^{237}$ To the degree that voluntariness under $\$ 201(\mathrm{e})$ is determined in reference to state law, this is a sound interpretation of the state community property law's default rules relating to place of marriage or change of domicile in determining property rights in property acquired during the marriage. ${ }^{238}$ However, rather than create legal default rules that presume through some attenuated process that starts with a decision to marry or to live in a community property state and concludes therefrom that there has been an initial voluntary transfer of a copyright, this article contends that the language of $\S 201(\mathrm{e})$ and the legislative purpose behind this section requires that each initial transfer of copyright must be accompanied by an objective manifestation of voluntary consent.

Commentators avoid the nettlesome constitutional and statutory questions presented by $\S 201(\mathrm{e})$ by weaving levels of legal fictions that create the illusion of voluntariness, permitting the conversion of an ownership of the federal copyright vested solely in the author-spouse into a species of community property with shared ownership transferred by

235 See Rodrigue I, 55 F. Supp. 2d 534, 542 (citing S. Rep. No. 95-989 (1978), reprinted in 1978 U.S.C.C.A.N. 5787 ; H.R. REP. No. 95-595, (1977), reprinted in 1978 U.S.C.C.A.N. 5963).

236 See i Patry on Copyright, supra note $36, \S$ I:83 (citing Act of Nov. 6, 1978, Pub. L. No. 95-598, 95th Cong., 2d Sess., 92 Stat. 2676) ("The first substantive amendment to the Act occurred in November 1978 , when Section 201 (e) was revised to permit involuntary transfers under the Bankruptcy Code.").

237 See Goldstein, supra note 2 I, § 5. I.6; Nimmer \& Nimmer, supra note 33, § 6A.03; PATRY supra note $36, \S 5: 116$. The danger of a doctrine of ambiguous consent vitiates Congress's intent to protect authors. Cf. Scheer v. Universal Match Corp., 4I 7 F.2d 497, 501 (2d Cir. 1969) (finding sculptural work created by two on-duty enlisted soldiers during the draft-era U.S. Army as the "suggestion" of a superior officer, the Deputy Post Commander, to be done as part of a "voluntarily formulated employment relationship" thus resulting in a work-for-hire).

238 See William Q. de Funiak \& Michael J. Vaughn, Principles of Community PropERTY $\$ 9 I$ (2d ed. 197 I); see also Tetry S. Kogan, A Neo-Federalist Tale of Personal Jurisdiction, 63 CAL. L. REv. 257, 324 (1990) ("The consent of the owner...places his property in a particular state, and subjects that property to the law of such state. The consent of the individual, in electing a particular land as his domicile, subjects him to the sovereign of that land, those laws he thus elects as binding on himself.") (citation omitted). 
' operation of state law.239 Leading commentators posit that by voluntarily entering into a marriage in a community property state or establishing residence in a community property state, an author also voluntarily agrees to one (or more) of the following: co-ownership (tenants-in-common) under Worth, a sharing of the fructus of the copyright under Rodrigue, or tertium quid-some new, and as yet unknown, ownership status(es) to be devised later. ${ }^{240}$ Allowing mere conduct without even an express oral agreement to determine voluntariness under $\S 201$ (e) seems to be at odds with the purposes behind $\S 204(\mathrm{a})$ and inconsistent with the purposes of the Copyright Act. ${ }^{241}$ To indulge in the fiction that consent to marry or to domicile in a community property state also constitutes an unknowing but voluntary prospective consent to alienate copyrights in works that have not yet been conceived renders the voluntary element of a $\$ 201(\mathrm{e})$ initial transfer of a copyright from an author vacuous, if not nugatory. ${ }^{242}$

The irony of this argument is demonstrated in the context of individuals marrying in a common law jurisdiction and then later moving to a community property jurisdiction. In the case of a relocating couple, a court must either refuse to indulge in the fiction that marriage in (or creation during marriage while domiciled in) a community property state constitutes a voluntary consent to division of copyright property through marriage, conclude the decision to remain married in a community property

239 See Goldstein, supra note $21, \S 5.1 .6$, at 5:22 to 5:23; Nimmer \& NIMMER, supra note 33, § 6A.03; PATRY supra note $36, \$ 5: 116$.

240 See Nimmer \& Nimmer, supra note $33, \S 6$ A.o3. Allowing mere conduct without even an express oral agreement to determine voluntariness under $\S 201(\mathrm{e})$ seems to be at odds with the purposes behind $\S 204(a)$ and inconsistent with the purposes of the Copyright Act. See Davis v. Blige, 505 F.3d 90, 108 (2d Cir. 2007) ("[T]he purpose of the writing requirement in the Copyright Act of 1976 was 'to protect copyright holders from persons mistakenly or fraudulently claiming oral licenses ....'”) (quoting Eden Toys, Inc. v. Florelee Undergarment Co., 697 F.2d 27, 36 (2d Cir. 1982)); Effects Associates, Inc. v. Cohen, 908 F.2d 555, 556-57 (9th Cir. 1990); Warner Bros. Pictures v. Columbia Broad. Sys., 2 I6 F.2d 945, 949 (9th Cir. 1954) ("The clearest language is necessary to divest the author of the fruits of his labor. Such language is lacking here."); PATry supra note $36, \$ 5: 106$. But see Nimmer on Copyright, supra note $37, \S 10.03$ [A][2].

24 I See Davis, 505 F.3d at 108 ("[T]he purpose of the writing requirement in the Copyright Act of 1976 was 'to protect copyright holders from persons mistakenly or fraudulently claiming oral licenses ....") (quoting Eden Toys, F.2d at 36); Effects Assocs., go8 F.2d at 557 Warner Bros, 2 I 6 F.2d at 949 (citation omitted) (internal quotation marks omitted) ("The clearest language is necessary to divest the author of the fruits of his labor. Such language is lacking here."); PATry supra note $36, \S$ 5: I06. But see Nimmer ON COPYRIGHT, supra note 37 , $\S 10.03[\mathrm{~A}][2], 10-45$.

242 See Black's Law Dictionary 17 Io (9th ed. 2009) ("voluntary, adj. ( I 4c) I. Done by design or intention <voluntary act>."). This interpretation of marriage truly gives a new meaning to the wedding vow, "With this ring I thee wed ... with all my worldly goods [including copyrights] I [voluntarily] thee endow." See Episcopal Church, Book of Common Prayer I 19 (2010). 
state is sufficient voluntary conduct to constitute a voluntary waiver of $\S 20 \mathrm{I}(\mathrm{e})$ rights, or find that the copyright remained vested in the author.

In jurisdictions recognizing post-cohabitation property rights analogous to those recognized in Marvin v. Marvin or jurisdictions like Washington state that recognize meretricious relationships, ${ }^{243}$ the conduct of sharing bed and board might suffice as conduct by which a court may infer a voluntary transfer of a copyright under $\$ 201(\mathrm{e})$. The cohabitation relationship is more problematic for the purposes of determining whether an initial transfer of copyright is voluntary; at least in the marital community property setting the author-spouse has formally and voluntarily entered into a legally binding relationship, which both spouses know will affect their economic rights in after-acquired property, However, in the case of cohabiting partners, there is no legal formality and the partners may not even be aware of the legal consequences of their relationship on their individual property rights until the relationship terminates and the court partitions the property.

Finally, one may speculate whether courts would find that the reverse is true and indulge in the legal fiction that changing one's domicile from a community property state constitutes a disavowal of any continued intention to make a voluntary copyright transfer for works created after domiciling in a common law jurisdiction. Alternatively, one might consider whether any court could view a move to a common law jurisdiction as a signal that there was never an initial intent either to voluntarily transfer co-ownership of the copyright or to share the economic proceeds with the non-author spouse by operation of the law. ${ }^{244}$

4. Federal Conflict or Field Preemption.-Absent the express preemption of a state law or a conflict between state law and the Constitution (or other federal law), state regulation may still be preempted by federal law if " $[t]$ he scheme of federal regulation [is] so pervasive as to make reasonable the inference that Congress left no room for the States to supplement it"; ${ }^{245}$ "the Act of Congress [] touch[es] a field in which the federal interest is so dominant that the federal system will be assumed to preclude enforcement of state laws on the same subject"; 246 or "the state policy may produce a result inconsistent with the objective of the federal stature." ${ }^{447}$

Copyright law arises out of an explicit grant of power to Congress in the United States Constitution. ${ }^{248}$ Congress's regulation of copyright is

\footnotetext{
243 See infra Part IV.

244 See generally Kingma, supra note 132 (discussing the property issues that spouses face in divorce, having resided in more than one state during marriage).

245 Rice v. Santa Fe Elevator Corp., 33 I U.S. 2 1 8, 230 (1947) (citations omitted).

246 Id. (citation omitted).

247 ld. (citation omitted).

248 U.S. ConsT. art. I, § 8, cl. 8; Sony Corp. of Am. v. Universal City Studios, Inc., 464 U.S. 417,460 (1984).
} 
comprehensive and plenary. ${ }^{249}$ The 1976 Copyright Act might better be called a copyright code. ${ }^{250}$ Congress has comprehensively legislated in all aspects of the life of a copyright from its "birth" to its "death" and ultimate entry into the afterlife of the public domain. Congress not only specifies that the copyright should initially vest in the author (without defining who is an author), ${ }^{251}$ but also creates different statutory authorial forms (e.g., individual authors, joint-authors, work-made-for-hire authors, and collective work authors) ${ }^{252}$ Congress also specifies specific processes and formalities for conveying subsequent legal ownership in the copyright depending on the legal form of the authorship. ${ }^{253}$ Congress has defined the scope of the subject matter of copyright ${ }^{254}$ and the timing of its initial vesting. ${ }^{255}$ Congress excludes U.S. government works from copyright protection. ${ }^{256}$ Congress provides for the exclusive rights that define the copyright ${ }^{257}$ then limits those rights ${ }^{258}$ and implements compulsory licenses. ${ }^{259}$ Congress has established the processes for transferring copyrights, established limitations on transfers of copyrights, and provided for the termination of transfers of copyrights. ${ }^{260}$ Congress has also created a registration process for copyrights, including a method for recording transfers of ownership or other interests in the Copyright Act that preempts state recordation systems. ${ }^{261}$ Congress

249 See Sony Corp. of Am. v. Universal City Studios, Inc., 464 U.S. 417, 419 ( 1984 ).

250 Cf. Dowling v. United States, 473 U.S. 207, 223 (1985) ("Congress adopted a comprehensive revision of the Copyright Act."); Johnston v. Smith, No. I:95-CV-595-RCF, 1997 WL 584349, at *2 (N.D. Ga. June 10, 1997) ("[T]he Copyright Act is . . a comprehensive legislative scheme....").

25 I See Merchant v. Levy, 92 F.3d 51,55 (2d Cir. 1996); Shubha Ghosh, Copyright As Privotization: The Case of Model Codes, 78 TuL. L. Rev. 653, 710 (2004). hire").

25217 U.S.C. $\$ 201(a)-(c)(2006)$; id. § ror (defining "joint work" and "work made for

253 See 17 U.S.C. $\$ 201(d)$.

25417 U.S.C. \$ I02 (2006); id. § 103; Reed Elsevier, Inc. v. Muchnick, I30 S. Ct. I237, I24I (2010) ("Congress has crafted a comprehensive statutory scheme governing the existence and scope of '[c]opyright protection' for 'original works of authorship fixed in any tangible medium of expression.") (citing 17 U.S.C. $\$ 102(a)$ ).

255 I 7 U.S.C. \$ 201.

$256 \quad 17$ U.S.C. $\S 105(2006)$.

257 I 7 U.S.C. $\$ 106(2006) ;$ see also id. $\$$ I 14.

$258 \quad 17$ U.S.C. $\$ \S 107-122$ (2006).

25917 U.S.C. \& I II, I 15, I 16, I 18 (2006).

26017 U.S.C. $\$ 204$ (2006); Gillespie v. AST Sportswear, Inc., No. 97 Civ. 19 I I (PKL), 200 I WL 180147 , at *7 (S.D.N.Y. Feb. 22, 2001) ("The Copyright Act prescribes a comprehensive scheme for the licensing of copyrighted works.").

26I 17 U.S.C. $\S \S 408-412$ (2006); Fodere v. Lorenzo, No. 09-CV-23 I 20, 20 I I WL 465468, at *2 (S.D. Fla. Feb. 4, 201 I) ("Title 17 of the United States Code lays out a comprehensive scheme for the registration and protection of copyrights in the United States."); Peregrine Entm't, Ltd. v. Capitol Fed. Sav. \& Loan Ass'n of Denver, I I6 B.R. I94, 199 (C.D. Cal. I990) ("[T]he comprehensive scope of the federal Copyright Act's recording provisions, along with 
provides for the rights of the author's survivors, ${ }^{262}$ defines and penalizes copyright infringement (including both civil and criminal penalties), ${ }^{263}$ establishes the term of copyright protection, ${ }^{264}$ and even defines terms such as "children," "widow," and "widower"265_legal status categories that Congress traditionally left by default or by design to the individual states. ${ }^{266}$ Finally, Congress ousts state courts from all copyright disputes arising under the Copyright Act and vests exclusive jurisdiction in the federal courts. ${ }^{267}$

That Congress intended for copyrights to be governed by federal law and construed by federal courts alone is further illustrated by the fact that where Congress wishes to defer to states in the Copyright Act, it does so unequivocally. For example, Congress enacted three specific statutory preemption provisions that preempt state law.. ${ }^{268}$ More subtly, while the Copyright Act defines the term "widow" or "widower" in reference to individual state law, ${ }^{269}$ Congress does not look to individual state law to define the term "children." 270 Further, while Congress permits a copyright itself to be bequeathed or pass through state intestate succession, ${ }^{271}$ it rejects state intestate succession or even voluntary bequests by the author

the unique federal interests they implicate, support the view that federal law preempts state methods of perfecting security interests in copyrights and related accounts receivable.").

26217 U.S.C. $\$ 203$ (2006).

26317 U.S.C. $\$ 501-508,510-513$ (2006); 17 U.S.C. $\$ \S 602,603$ (2006); Molinelli-Freytes v. Univ. of P.R., 727 F. Supp. 2d 60, 66 (D. P.R. 2010) ("[T]he Copyright Act provides a comprehensive and detailed damages scheme. . . "); Gemcraft Homes, Inc. v. Sumurdy, 688 F. Supp. 289, 293 (E.D. Tex. 1988) ("The Copyright Act, like ERISA, provides a comprehensive scheme of remedies for violations. ..."); Dodd v. Fort Smith Special Sch. Dist. No. I00, 666 F. Supp. 1278, 1283 (W.D. Ark. I987) ("[T]he Act provides a comprehensive enforcement scheme and remedies for infringement of copyright.").

264 See 17 U.S.C. \$§ 302-305 (2006).

26517 U.S.C. $\$$ 101 (2006).

266 See De Sylva v. Ballentine, 35 I U.S. 570, 580 ( I956); Fierro v. Reno, 2 I 7 F.3d I, 3-4 (Ist Cir. 2000).

26728 U.S.C. \& $1338(a)$ (2006) ("The district courts shall have original jurisdiction of any civil action arising under any Act of Congress relating to ... copyrights . . . No State court shall have jurisdiction over any claim for relief arising under any Act of Congress relating to . . . copyrights."). See also section III.A.

268 I 7 U.S.C. $\S 201(e) ;$ I 7 U.S.C. $\S 301$ (a), (f) (2006).

269 I 7 U.S.C. $\$ 10$ I ("The author's 'widow' or 'widower' is the author's surviving spouse under the law of the author's domicile at the time of his or her death, whether or not the spouse has later remarried.").

270 Id. ("A person's 'children' are that person's immediate offspring, whether legitimate or not, and any children legally adopted by that person."), legislatively overnuling De Sylva, 35 I U.S. at $580-8$, (looking to state law to define "children").

27117 U.S.C. $\$ 201$ (d) (2006). The recordation provisions of the Copyright Act govern disputes regarding subsequent transfers of the copyright while "[s] tate law governs all other aspects of copyright mortgages, including construction, effect and foreclosure." PAuL GoLDSTEIN, GoldSTEIN ON COPYRIGHT, § 5.1 1.5, 5:19 n.68 (Supp. 2007). 
of the author's copyright termination rights. ${ }^{272}$ Final evidence of Congress's preemptory intentions is that federal courts do not usually refer to the laws of one particular state when asked to interpret the Copyright Act; rather, they often create federal common law. ${ }^{273}$

Copyright is an area of federal law where national uniformity is paramount. ${ }^{274}$ Applying the laws of different community property states (or equitable distribution states) will.result in a chaotic body of postdissolution copyright ownership law. ${ }^{275}$ This cacophony of conflicting law will rise to a crescendo as common law states, equitable distribution jurisdictions, and jurisdictions that provide some property protection to unmarried cohabiting couples join in the chorus of state courts opining on copyright ownership. ${ }^{276}$

Congress enacted a comprehensive statutory copyright scheme that both expressly and implicitly displaces state law through a blend of express, conflict, and field preemption. Copyright law is now a significant foreign relations issue, and the Copyright Act has been amended to conform to the United States's treaty obligations under the Universal Copyright Convention, the Berne Convention, and TRIPS. ${ }^{277}$ In the arena of international relations it is particularly important that the United States speak with one consistent voice. ${ }^{278}$

In the Copyright Act, Congress specifically excludes the states from regulating in many areas, including in certain aspects of family law, an area in which the state's police powers are historically treated as paramount in our federal system. Congress defines family law terms for Copyright Act purposes in a manner that may be inconsistent with a state's definition of the term. Congress also displaces state law dealing with the transfer

27217 U.S.C. $\$ 203(a)(2)(D)$ (2006).

273 See, e.g., Cmty. for Creative Non-Violence v. Reid, 490 U.S. 730, 740 (1989); Cincom Sys., Inc. v. Novelis Corp., $5^{81}$ F.3d 43 I , 436 (6th Cir. 2009).

274 See Cmty. for Creative Non-Violence, 490 U.S. at 740; Bonito Boats, Inc. v. Thunder Craft Boats, Inc., 489 U.S. I4I, 163 (1989); Goldstein v. California, 412 U.S. 546, 551 ( I973); THE Federalist No. 43 (James Madison).

275 Compare In re Marriage of Worth, 24I Cal. Rptr. 135, 140 (Cal. Ct. App. I987) (finding that divorced spouses are co-owners of the copyright), and Rodrigue II, 218 F.3d 432, 435-36 (5th Cir. 2000) (finding that author-spouse has ownership-management rights but must share fruits of the copyright), with Nevins, Jr., supra note 87, at 5 1 7-18, and Patry, supra note 158 (comparing Texas and California community property statutes). See generally Kingma, supra note 132 .

276 See Moore v. Ferrie (In re Marriage of Moore \& Ferrie), i 8 Cal. Rptr. 2d 543, 547 (Cal. Ct. App. 1993); In re Estate of Kessler, 203 N.E.2d 221, 222-23 (Ohio 1964); 15B AM. Jur. 2D Community Property § 17 (2011).

277 See Golan v. Holder, 132 S. Ct. 873, 879-82 (2012) (discussing the Berne Convention and TRIPS); Mills Music, Inc. v. Snyder, 469 U.S. I 53, I 59-60 ( 1985 ). See generally S. REP. No. 352, ( 1988 ), reprinted in 1988 U.S.C.C.A.N. 3706 ,

278 Cf. Zschernig v. Miller, 389 U.S. 429, 440-4I (1968) (determining that states may not establish their own "foreign policy" through their probate courts). 
of copyrights by enacting specific provisions that might be described as the micromanagement of bequests and intestate succession. ${ }^{279}$ Courts have repeatedly referred to the 1976 Copyright Act as a comprehensive scheme. Other bodies have treated it as a comprehensive scheme, too. For example, Uniform Commercial Code Article 9 provisions yield to federal law regarding how to perfect a security interest in a registered copyright. ${ }^{280}$ In sum, the express preemption provisions of the Copyright Act, the apparent conflict between state laws governing property at the dissolution of a relationship and federal copyright law, and a clear intent by Congress to occupy the field of copyright law and to displace most state law in the area lead inescapably to the conclusion that state domestic relations law must yield to federal copyright law.

\section{E. Preemption, Community Property, and Termination of Transfer Rights} (17 U.S.C. § 203)

One of the rights of an author under copyright law is the right to terminate the transfer of copyright ownership, including lesser nonownership rights such as a non-exclusive license. ${ }^{281}$ Therefore, regardless of what a state court may decree as part of the property settlement, Congress has vested in the author-spouse, the widow(er), and the author's children the ultimate right to terminate that transfer. Importantly for the analysis, " $[t]$ ermination of the grant may be effected notwithstanding any agreement to the contrary, including an agreement to make a will or to make any future grant." 282 'Thus, even if a state's law assumes that the author-spouse granted an interest in the copyright through the voluntary act of marriage, the author-spouse may still terminate that transfer under $\$ 203$. To exercise the termination right, the author-spouse or the author-spouse's statutory heirs must give notice neither less than two nor more than five years after thirty-five years have passed since the initial transfer. ${ }^{283}$

A related section, $\S 203(b)(5)$, appears to superficially limit the application of $\S 203(a)(5)$. Section $203(b)(5)$ provides that "[t]ermination of a grant under this section affects only those rights covered by the grants that arise under this title, and in no way affects rights arising under any

279 Cf. Tritt, supra note 15, at 182-84 (circumventing copyright law with will contracts).

280 See U.C.C. \$\$ 9-1 og(c)(1), 9-3I I(a) (1998); In re World Auxiliary Power Co., 303 F.3d I 1 20, I 127 (9th Cir. 2002); Nat'l Peregrine, Inc. v. Capitol Fed. Sav. \& Loan Ass'n of Denver (In re Peregrine Entm't, Ltd.), 116 B.R. 194, 200 (C.D. Cal. 1990).

281 i 7 U.S.C. $\$ 203$ (a) (2006).

282 i 7 U.S.C. $\$ \S 203(\mathrm{a})(5), 304(\mathrm{c})(5)$; see 7 Patry on Copyright, supra note $36, \S 25: 74$, nn. $5-6(2012)$.

283 Of course, if state law or the agreement permits, the rights may be terminated prior to the thirty-five year period. See Walthal v. Rusk, 172 F.3d 481, 485 (7th Cir. 1999); Korman v. HBC Fla., Inc, I82 F.3d I29I, 1295 (I Ith Cir. 1999). But see Rano v. Sipa Press, Inc., 987 F.2d 580,585 (9th Cir. 1993). 
other Federal, State, or foreign laws." Yet the legislative history clearly states:

\begin{abstract}
Nothing contained in this section or elsewhere in this legislation is intended to extend any license or transfer made for a period of less than thirty-five years. Likewise nothing in this section or legislation is intended to change the existing state of the law of contracts concerning the circumstances in which an author may terminate a license, transfer or assignment. [Section 203(b)(6)] provides that unless and until termination is effected under this section, the grant, "if it does not provide otherwise," continues for the term of copyright. The quoted language means that the agreement does not provide for a term of less than thirty-five years. 284
\end{abstract}

From this explanation, it is clear that $\$ 203(\mathrm{~b})(5)$ would not provide a state law exception to the author's termination rights in order to accommodate a settlement or court decree in a marital dissolution proceeding in a community property state.

In the context of community property law, it is not clear when the transfer originally took place. If under state law the non-author spouse accrued an "operation by law transfer" upon the creation of a work during marriage then that would start the thirty-five year period. However, if the transfer does not take place until the entry of the court order allocating the individual interest in the copyright, that would then be the starting point to determine when the thirty-five year period commenced.

Probably the better interpretation of when the initial transfer occurs under community property law is upon the fixation of the copyrighted work. ${ }^{285}$ The court decree dividing the copyright interests vested in the marital community is not a new transfer. ${ }^{286}$ It is merely an award of the existing copyright interest that was initially transferred from the author by operation of state law. Therefore, the transfer that the author-spouse may seek to terminate is the initial one to the marital community. Terminating this initial transfer will also terminate any subsequent transfer by either pre-dissolution by the marital estate or by the court in the dissolution proceeding. This could lead to ludicrous results where a spouse of many years finds that the copyrighted work is transferred out of the marital estate and a brand new spouse may enjoy the fruits of the copyright for many years to come. Yet it is a more principled rule than to assume either that the copyright is separate property (thus never entered into the marital estate) or that it exists in the ether of property law and is to be characterized and

284 S. REP. No. 94-473, at I 25 (1975).

$285 \mathrm{See} 17$ U.S.C. $\$ 102(2006)$.

286 A settlement agreement is more problematic. The language of the settlement agreement could create a new transfer of the copyright or potentially, if the settlement is in the termination period, waive the right to terminate the transfer. See Milne ex rel. Coyne v. Stephen Slesinger, Inc., 430 F.3d 1036 (9th Cir. 2005), cert. denied, 548 U.S. 904 (2006). 
transferred only when a court so orders. Whatever rights the divorced spouse may claim under state law, federal law is clear that the termination right may be exercised only by the author, the author's statutory heirs under the Copyright Act, or, if no surviving statutory heirs, the executor of the author's estate. ${ }^{287}$

In sum, the termination of transfer right presents numerous problems in the allocation of copyrights in a divorce proceeding, all of which raise issues of preemption. First, as mentioned above, regardless of the status of the copyright under state law as marital property, whatever state courts order as part of a divorce proceeding, or even if the divorce settlement is voluntary, the author-spouse has an unwaivable federal right to terminate the transfer of the copyright. ${ }^{288}$ Second, regardless of the intent of the author or the courts, if the author does not survive into the period in which he or she may elect to terminate the transfer, then the termination right statutorily vests in the author's then-widow(er) and children (per stirpes) and not in the divorced spouse. ${ }^{289}$ Under copyright law, it is the widow(er) or children who may exercise these rights rather than the divorced spouse. ${ }^{29 \circ}$ Consequently, even if a copyright becomes part of the community property estate by operation of law, it will remain there at the sufferance of the author-spouse, and a state court's ability to manage the copyright assets as part of the divorce proceeding is extremely limited.

\section{F. Summary of Copyright Preemption}

Despite the leading cases of Worth and Rodrigue, whether a copyright can be conveyed through operation of law in a community property state is still an open question. ${ }^{291}$ In its opinion, the Worth court did not consider

287 i 7 U.S.C. $\$ 203(a)(2)$. See I-6A Nimmer \& Nimmer, supra note 33, § 6A.03[C][ I].

288 See 17 U.S.C. \& 203(a)(5); N \& D E Co. v. Gustings, Civ. A. No. 90-4445, 1992 WL $775^{8 \mathrm{I}}$, at ${ }^{*} 4$ (E.D. La. April 9, 1992).

289 See Broad. Music, Inc. v. Roger Miller Music, Inc., 396 F.3d 762, 77I (6th Cir. 2005); Troutman v. Estate of Troutman, 937 N.E.2d 173, 177 (Ohio Ct. App. 2010).

290 Under the Copyright Act, the question of who is an eligible widow(er) is determined in reference to state law. 17 U.S.C. § I0I (2006) ("The author's 'widow' or 'widower' is the author's surviving spouse under the law of the author's domicile at the time of his or her death, whether or not the spouse has later remarried."). States seem to preclude a divorced spouse from the privileges of widow(er)hood. See, e.g., McCarthy v. Schwerin (In re McCarthy's Estate), 73 P.2d 910, 910-I I (Cal. Cr. App. 1937); Opdahl v. Johnson, 28 N.E.2d 308, 310 (Ill. Ct. App. 1940); In re Chomsky's Estate, I0I N.Y.S.2d 60, 6 I (Sur. Ct. 1950); see also Howard B. Abrams, 2 The Law of Copyright \& 12:2 I (201 I); Nevins, Jr., supra note 87, at 510-12.

291 See PatrY supra note 36, § 5:1 16. California has a sui generis statutory law of community property. See BASSETT, supra note 17, § 1:4. In Rodrigue II, the Fifth Circuit relied on a unique aspect of Louisiana civil law, which is the only civil law jurisdiction in the United States. Accordingly, these cases regarding community property may be only instructive in their specific jurisdictions. See Nevins, Jr., supra note 87, at 517-18. Lawyers with clients who have assets in community property jurisdictions are advised to consider whether to address 
$\S 201(\mathrm{e})$ when it analyzed whether the general principles of $\S 201$ preempted California's community property laws insofar as they purported to convert the sole copyright ownership of the authoring spouse to one co-owned with the non-authoring spouse. ${ }^{292}$ By contrast, the Rodrigue II avoided the $\S 201$ (e) issue by focusing instead on the $\S 106$ exclusive rights that constitute the copyright as a property right bundle of sticks. Specifically, the Rodrigue II court severed copyright ownership into the right to manage or control the alienation or licensing of the copyrighted and the right to receive the economic benefits that flow from the alienation or licensing of the work. ${ }^{293}$ The court thus converted a copyright estate of tenancy in its entirety into a new previously unknown legal estate, a sort of pseudo"profit a prendre," with a half-benefit to the non-author spouse through a novel and strained interpretation of Louisiana community property law. The author-spouse retained the right to manage the copyrighted work, but he had to share the economic proceeds derived from his copyright with the non-author spouse.

No court has yet addressed federal preemption under $\S 106 \mathrm{~A}$, the Visual Artists Rights Act, in the context of a state community property dissolution proceeding. Consequently, jurists, scholars, and commentators are left to speculate about the effects of VARA on marital dissolutions that must account for author's moral rights in works of visual art. Divorce law practitioners, estate planners, and attorneys for the creative content industries are left to engage in costly prophylactic planning for theoretical possibilities regarding how each state's community property law and the federal law governing copyright ownership may develop over time in different federal circuits and state courts. There is a real possibility that state court judgments regarding copyright ownership may have to be relitigated in federal court before questions regarding title are authoritatively settled.

\section{Love and Marriage and Partnership}

Both principles of sound copyright law and policy and the law of federal preemption require that copyright law and state law be harmonized in order to promote the progress of science and the useful arts as provided

intellectual property assets, especially copyrights and patents, in a prenuptial or postnuptial agreement. Regardless of whether it is a community property jurisdiction or a common law equitable distribution jurisdiction, lawyers licensing copyrights or purchasing copyright assets may wish to obtain consent from all parties in the marital community. See, e.g., Rodrigue v. Rodrigue, Civ. A. No. 95-2862, 1996 WL 109309, at *2 (E.D. La. March 13, 1996) ("[Spouse argued that the contract was void because she] was not aware of, did not agree to the contents of the agreement and the amendment nor did she renounce her right to concur in the alienation of the community owned artwork.").

292 In re Marriage of Worth, 24I Cal. Rptr. I35, I40 (Cal. Ct. App. 1987).

293 Rodrigue II, 2 I 8 F.3d 432, 436-37 (5th Cir. 2000). 
for by the Constitution. Harmonization will promote finality in the state proceedings that terminate the social and economic relationship subsumed in the marital construct. This section will explore the nature of a business partnership and whether the economic aspects of the marital relationship may be instantiated or distilled into form of a legal partnership. While this section of the article will theorize on whether a community property marriage is also a business entity partnership, the following section will discuss the advantages of treating the marriage as a partnership under copyright law.

Marriage has or is at least reputed to have a dual nature. To some, marriage is the legal embodiment of the symbolic or spiritual union of two people becoming one flesh. ${ }^{294}$ But marriage is also an institution in which two distinct individuals enter into a commercial relationship. ${ }^{295}$ This commercial relationship may be analogized to a business entity partnership, and this article argues that it is this view of the marriage that should be the focus for determining marital property distribution issues that involve ownership of copyrighted works. ${ }^{296}$ The dual nature of marriage is recognized in community property jurisdictions. For example, a spouse may petition a court to to partition the community property (including its profits and losses) without terminating the legal marriage. ${ }^{297}$ The marital community as a legal entity separate and apart from the individual spouses is well established in some states. ${ }^{298}$ The social and economic duality of marriage, from its historic religious underpinnings and overt sexuality to its economic aspects, has rendered marriage a fetish to the judiciary and legislatures. Judicial and legislative anxiety about the nature of the relationship has resulted in laws and policies that conflate love, marriage, sex, and the economic union of two people. An inordinate fear of reducing marriage to sex and money has rendered many a jurist or legislature impotent. ${ }^{299} \mathrm{By}$

294 See Barber v. Barber, 62 U.S. 582, 588-89 (1858); Genesis 2:24 ("Therefore a man leaves his father and his mother and cleaves to his wife, and they become one flesh."); see also Barbara Engler, Personality Theories: An Introduction 352 (8th ed. 2009) (describing marriage as meeting a higher order need); Robert P. George \& Gerard V. Bradley, Marriage and the Liberal Imagination, 84 GEo. L.J. $301,307-08$ ( 1 995 ).

295 See Wissiner v. Wissiner, 338 U.S. 655,660 ( 1950 ) ("[T]he community property principle rests upon something more than the moral obligation of supporting spouse and children: the business relationship of man and wife for their mutual monetary profit."). $C f$. Eisenstadt v. Baird, 405 U.S. 438,453 (1972) ("Yet the marital couple is not an independent entity with a mind and heart of its own, but an association of two individuals each with a separate intellectual and emotional makeup.").

296 See generally DE FuniaK AND VAUghn, supra note 238, \$ 95 (describing the nature of a community property jurisdiction marriage as a "general partnership").

297 See de Funiak and Vaughn, supra note 238 , \$ 129.

298 See, e.g., Keene v. Edie, 935 P.2d 588, 584 (Wash. 1997).

299 Cf. Marvin v. Marvin, 557 P.2d 106, 110 (Cal. 1976) ("The courts should enforce express contracts between nonvarital [sic] partners except to the extent that the contract is explicitly founded on the consideration of meretricious sexual services."). 
contrast, in cohabitation arrangements outside of marriage, courts have used contract or business entity principles to analyze cohabitation agreements in order to create default rules regarding.allocating property acquired during the period of cohabitation. ${ }^{300}$ Courts have been willing to recognize these new legal relationships and endow them with quasi-community property status regarding any property acquired during the relationship. But courts will only recognize these relationships to the degree that they can segregate the non-sexual nature from the sexual nature of the exchanges between the parties in the relationship. Consequently, board but not bed is valid consideration for the allocation of property acquired during the relationship. ${ }^{301}$

\section{A. Partnership as Marriage and Marriage as a Business Association}

It is said that while marriages are made in heaven, they are lived on earth. Therefore, while marriage (or cohabitation) is, on the one hand, a unique, unquantifiable human relationship whose contours are outside the scope of this article, in daily life, marriage is also an economic relationship. On the romantic partnership side of a marriage, the couple produces goods and services for intra-family or household consumption (internal production). More importantly for this article, the business partnership institution within a marriage produces goods and services for external trade (external production) in order to promote the economic well being of the couple. This article contends that the external trade production aspect of the economics of a marriage is analogous to the economic activities of a business partnership. This is significant because if the marital relationship is a business partnership, then the author-spouse's copyrighted works fit into a well-established model for disposing of partnership assets at the dissolution of the partnership, thus avoiding the thorny issues of state and federal preemption.

Perhaps a hypothetical moving from a conventional business partnership to a marriage entity business partnership could make this point clearer that there is no legal distinction between spouses as marital partners and spouses

300 See id.; Amanda J. Beane, One Step Forward, Two Steps Back: Vasquez v. Hawthorne Wrongly Denied Washington's Meretricious Relationship Doctrine to Same-Sex Couples, 76 WaSH. L. Rev. 475, 477 (2001) ("Property division at the end of a relationship that does not qualify as a meretricious relationship is dependent on contract, partnership and restitution remedies.").

301 In re Marriage of Lindsey, 678 P.2d 328, 307 (Wash. 1984); Pennington v. Pennington (In re Marriage of Pennington), 97 I P.zd 98, 10I (Wash. Cr. App. 1999) ("In analyzing whether a meretricious relationship exists, a court may consider the following non-exclusive factors: (I) continuity of cohabitation; (2) duration of the relationship; (3) purpose of the relationship; (4) pooling of the resources and services to accomplish common goals and projects; and (5) intent of the parties.") (quoting Connell v. Francisco, 898 P.2d 83 I (Wash. 1995). See generally Gavin M. Parr, What Is a "Meretricious Relationship"?: An Analysis of Cohabitant Property Rights Under Connell v. Francisco, 74 WASH. L. Rev. I 243 ( I999). 
as a business entity partnership. Assume three individuals with different skill sets: Toby is a talented writer; Lexi has fiscal resources; and Annie is a skilled typist. ${ }^{302}$ Lexi, Annie, and Toby agree that Lexi will provide Toby with financial support (capital contribution), Annie will provide secretarial support (in kind contribution), and Toby will write the book (copyrighted work and in-kind contribution), and that when the book is published, they will split the profits from the book and the book's derivative works, if any. They also agree that if the book is a failure that they will share the losses. The book is published; each individual takes a one-third share of the royalties and deposits his or her check into a separate bank account. This arrangement could be described as a common business partnership.

Eventually, two of our three partners, Lexi and Toby, fall in love and get married. This marriage would not convert a business partnership composed of Lexi, Toby, and Annie into some non-business entity enterprise. ${ }^{303}$ The married couple Lexi and Toby would have a marriage partnership while Lexi, Toby, and Annie would still be individual partners in a separate legal entity business partnership. Lexi and Toby would still receive their respective individual shares of the profits from the partnership. This result should not change even if, by operation of state law, the profits from the partnership become community property held jointly by Lexi and Toby as spouses-incommon. Lexi and Toby's liabilities for the debts of the partnership remain the same, though the amount might be paid individually out of separate property or collectively out of community property depending on the state where they are married. But in this hypothetical, because they share all post-marriage earnings as a marital community or receive the same share of profits as separate property, the net effect on Lexi-Toby's assets would be the same. Nor should the business partnership status of this arrangement change if Annie decides to leave the partnership. In that case, after the winding down of Annie's interest in the partnership, Toby and Lexi would remain both spousal-partners and legal business-partners as they continue to exploit the copyright in the book through licensing or conveyance (external production). However, while the distinction between marriage partners and business partners is legally and economically significant, unless Toby and Lexi divorce, this is a distinction that is without practical significance.

Once the fundamental economic nature of marriage has been discerned, the question is whether this economic institution may be understood in light of analogous institutions. ${ }^{304}$ The expression of marriage as a partnership is

302 If you are trying to figure out who the author is writing about, the names belong to a friend's cats.

303 One way of conceptualizing this relationship is as investment in human capital. See generally Gary S. Becker, Human Capital: A Theoretical Empirical ANalysis with Special Reference to Education (Nat'l Bureau Econ. Research 2d ed. 1975).

304 See Martha M. Ertman, Marriage As a Trade: Bridging The Private/Private Distinction, 36 
more than a polite metaphor; rather, at its core it expresses an economic truth that marriage may be a legal business entity partnership. ${ }^{305}$ The Revised Uniform Partnership Act (RUPA) defines a partnership as "the association of two or more persons to carry on as co-owners a business for profit ... whether or not the persons intend to form a partnership." 306 Partnership law recognizes that a husband and wife may be business partners. ${ }^{307} \mathrm{~A}$ neutral examination of the economic aspects of marriage suggests that it can be properly understood under the laws governing a business partnership. Therefore, this section will evaluate whether a marriage in a community property state may also constitute a legal business partnership.

The author concedes that despite the operational reality of intraspousal economic transactions, courts are extremely reluctant to treat customary social and financial intra-family exchanges as commercial transactions that support finding a distinct business partnership within a marriage, regardless of whether the same objective economic behavior in an arm's length transaction between strangers would constitute adequate evidence of a business partnership. In determining whether an entity is

HARv. C.R.-C.L. L. Rev. 79, $117-18$ (2001).

305 The IRS, the least romantic of the many phlegmatic federal agencies, recognizes the family partnership and provides special statutory provisions for family partnerships. 26 U.S.C. $\$ 704(e)$ (2006). The IRS also recognizes the sui generis nature of the intra-family commercial transaction. See id. Also, many non-traditional families use a legal business-entity partnership as an alternative to or in order to strengthen personal domestic partnership agreements. See Jennifer Tulin McGrath, The Ethical Responsibilities of Estate Planning Attorneys in the Representation of Non-Traditional Couples, 27 SEATTLE U. L. REv. 75, 85-86 (2003). Some commentators suggest marriage is more analogous to a closely held corporation. See Ertman, supra note 304, at $117-19$.

306 Revised Uniform Partnership Act (RUPA) § 202 (1997); see also id. § $101(6)$; Uniform Partnership Act (UPA) § 6( I) (1914).

307 See, e.g., Chocknok v. State, 696 P.2d 669, 673 n.4 (Alaska 1985); Gammill v. Gammill, 510 S.W.2d 66, 68 (Ark. I974); Lobato v. Paulino, 8 N.W.2d 873, 876 (Mich. I943) ("A partnership is an association of two or more persons (which may include husband and wife) to carry on as co-owners a business for profit."). At common law, spouses could not be business entity partners. See Lord v. Parker, 85 Mass. (3 Allen) I27, I 28 (186I ). At one point in time, based on antiquated and gendered notions regarding the economic role and business acumen of a woman in managing community assets, there was a dispute as to whether spouses could be partners in community property states. See William Q. de Funiak \& Michael J. Vaughn, Principles of Community Property $\$ \S$ I48-49 (2d ed. I 97 I). de Funiak \& Vaughn concluded that "There would seem to be no reason, however, why the spouses might not by antenuptial contract or by contract during marriage, in those state permitting it; provide that the legal community should not govern their property and that they should proceed on the basis of commercial partners...."Id. $\$ 148$. Modern laws regarding gender equality appear to have removed these difficulties. Compare id. $\$ 148$, with Alexandria Streich, Spousal Fiduciaries in the Marital Partnership: Marriage Means Business but the Sharks Do Not Have a Code of Conduct, 34 IDaHo L. Rev. 367,376-77 (1998) ("By 1979, all eight community property states had amended their statutes to eliminate discriminatory male management practices"). The fact that only recently could women fully participate in the economic management and life of the family might explain why the case law regarding spouses as business partners is so underdeveloped. 
both a marriage partnership and a commercial partnership. under state law, this article posits that courts should look to the underlying economic reality of the institution rather than treating the parties' understanding of the relationship, religious traditions, or social conventions of marriage as dispositive. Just as courts have moved beyond legal marriage as the sine qua non of legally protected relationships and are now protecting cohabiting individuals, courts should also be willing to move beyond the social relationship construct of marriage to determine that the foundational economic realities of the relationship are dispositive as to whether there is also business partnership. If courts (or state legislatures) took the next step out of their comfort zones to look objectively at the institution of marriage and the external economic relations of the marriage, then a fair balancing of the factors used to determine whether a social or economic relationship is also a legal business partnership would often weigh in favor of finding that the couple are not only spiritual partners but also legal business partners.

1. Two or More Partners.-The first element of the test to determine whether an association legally qualifies as a partnership is that a partnership requires two or more persons. ${ }^{308}$ This element is readily satisfied by most marriages or relationships. ${ }^{309}$

2. Co-ownership.- The second element in determining whether a marital relationship may be characterized as a partnership is whether the economic relationship among the participants is one of co-ownership over the assets. ${ }^{310}$ The essential elements of co-ownership are profit and loss sharing, control over the business, contributions to equity, and property-co-ownership. ${ }^{311}$ Co-ownership and control of property are the salient characteristics of a business partnership that distinguish it from other potentially complex economic relationships. The economic relations between creditordebtor, employer-employee, landlord-tenant, or franchisor-franchisee relationships may mimic the business partnership form in certain aspects, but they lack the necessary substantive qualitative similarity to meet the statutory definition. ${ }^{312}$ These non-partnership arrangements may provide for a share of the royalties (profits) from the on-going business entity, but usually involve no sharing of control over property, no sharing of the risk of

308 RUPA § 202.

309 See RUPA § 10I(Io) (defining "person"); Unif. Marriage \& Divorce Act $\$ 20$ I ( 970 ), 9A U.L.A. I75 (I998); Principles of the Law of Family Dissolution: Analysis and RecomMENDATIONS $\$ 6.03$ (Tentative Draft 2000) (" $[D]$ omestic partners are two persons of the same or opposite sex, not married to one another ....").

3 I0 RUPA § 202.

3 I I J. William Callison \& Maureen A. Sullivan, Partnership Law and Practice: General and Limited Partnerships § 5:1 I (201 I). See RUPA § 202(a); UPA § 6(1).

312 Callison \& Sullivan, supra note 3 I I, \$§ 5: I I-I 2. 
loss, no sharing of the liabilities of the business, and no agency relationship that permits the other party to legally bind the business.

\section{a. Agreement to Share Profits and Losses is "Prima Facie" Evidence of a Partnership}

Section 18(a) of the Uniform Partnership Act presumes that the contribution of each partner is equal and that each partner will share equally of the partnership's profits and losses unless the partners agree otherwise. ${ }^{313}$ Community property law makes the same assumption regarding marital assets. ${ }^{314}$ There is no inherent conflict between business entity law and community property law, so the factor of equal sharing of profit and loss may weigh in favor of finding that some marriages also constitute business partnerships. However, in applying these laws, judges have often found it difficult to focus on the family as a profit making institution as well as a romantic social institution in practice.

Only poets and economists may care to speculate on whether most marriages are profitable. However, a partnership does not actually have to generate a profit as long as the parties enter into the relationship with an expectation of earning and sharing the profits. A necessary corollary to the expectation of earning profits is the realization of the risk that the partnership may also incur losses and an appreciation of how these losses will be allocated among the partner-participants. ${ }^{315}$ There is no requirement that there be an explicit agreement to share losses; rather, courts often infer a sharing of the risk of loss from the agreement to share profits or from the partnership relationship itself. ${ }^{316}$ The traditional wedding vow "to have and to hold from this day forward, for better, for worse, for richer, for poorer" explicitly recognizes this economic reality of the risk sharing nature of marriage. ${ }^{317}$ Parties to a community property marriage explicitly agree to share profits and losses. ${ }^{318}$ Courts have distinguished the payment of profits from a partnership as wages from the receipt of profits as a return on investment. ${ }^{319} \mathrm{~A}$ receipt of profits as a return on investment is evidence of a partnership while payment of wages is merely evidence of

313 RUPA § 401(b) (1997); UPA § 18(a) (1914).

314 See Rosenbloom v. Rosenbloom, 851 So. 2d I90, I91 (Fla. Dist. Ct. App. 2003).

315 Callison \& Sullivan, supra note 311 , \$ 5:14.

316 See Crest Constr. Co. v. Ins. Co. of N. Am., 417 F. Supp. 564, 569 (W.D. Okla. 1976).

317 See Williams v: Williams, 543 P.2d 1401 , 1402 (Okla. 1975) (declining to enforce the ecclesiastical vows of marriage).

318 See Wissner v. Wissner, 338 U.S. 655, 660 (1950). See also Alexandria Streich, Spousal Fiduciaries in the Marital Partnership: Marriage Means Business but the Sharks Do Not Have a Code of Conduct, 34 IDaHo L. Rev. 367, 39 I (1998).

319 Lobato v. Paulino, 8 N.W.2d 873, 876 (Mich. 1943). 
employment. ${ }^{320}$ The profits from the external economic relations of the couple are analogous to a return on investment or the running of a small business therefore they should be evidence of a business partnership even if the profits are not actually distributed to the parties until the point of dissolution or death of a spouse.

The critical distinction in the marriage context is between "sharing gross returns as a family, which was not evidence of partnership, and a 'division' of profits, which would be evidence of partnership." ${ }^{321}$ In Spence $v$. Tatum, there was no attempt to segregate business assets from personal assets, and the court found that spouse's use of the "partnership" checking account to pay family bills and personal expenses such as a hairdresser, restaurant meals, and maid service was not sufficient to make the spouse a business partner. ${ }^{322}$ Further, the spouse's share was drawn from the "gross profits" of the business. ${ }^{323}$ This analysis appears to be a vestigial legacy of the fiction that marriage produced one legal entity and one person. It may also have been based in a chivalric desire to shield family assets from the imprudent business activities of the other spouse. During the marriage, the family without an individualized accounting may informally agree to share the revenues of the economic partnership as individuals in the marriage partnership. Clearly at the point of marital dissolution (either by divorce or death) the goal of the court is to properly allocate all of the profits that belong to the spouses as individuals, and individual charges that were not properly attributable to the community are deducted from each partner's share of the profits. ${ }^{324}$ At this point in time, the marriage partnership most closely mirrors the traditional business entity partnership and their innate similarities are most visible.

Courts have failed to articulate any rationale either under principles of family law or under principles of business partnership law to support an artificial distinction between joint-economic activities of married individuals and the economic activities of unmarried individuals when determining whether identical objectively measured activities should be weighed differently when determining whether an economic relationship meets the definition of a business partnership. ${ }^{325}$ The better interpretation

$320 \mathrm{Id}$.

32 I Spence v. Tatum, 960 F.2d 65, 68 (8th Cir. 1992).

322 Id. at 67-69. Another way of looking at these transactions is as partnership draws against profits that would later be accounted for when at the dissolution of the marriage when the profits and looses are allocated to each member of the community. See Baltrusch v. Baltrusch, 190 P.3d I034, 1038 (Mont. 2008).

323 Spence, 960 F.2d 65 at 68.

324 See, e.g., DE FUNIAK \& VAUGHN, supra note $238, \$ 223$ (debts to creditors); $\$$ I 75 (spouses as creditors of each other); $\$$ i 9 (mismanagement of community property); $\$$ I 20 (self-dealing and other breaches of fiduciary duties).

325 The best articulation of some support for this tendentious practice is found in Cooper v. Spencer, 238 S.E.2d 805 (Va. 1977). The court focused on the subjective understanding 
of modern partnership law would be to harmoniously interpret family law and partnership law by applying the same test to entities composed of individuals married to each other, single individuals who are romantically involved and strangers who undertake a business for profit.

\section{b. Mutual Right of Control or Management of the Business}

One of the salient attributes of co-ownership is the mutual right to control or manage the business. ${ }^{326}$ The control does not have to be extensive; it is sufficient to retain minor rights of control. ${ }^{327}$ The partners may agree to contract away the right to control. ${ }^{328}$ Analogously, in a community property jurisdiction, "[e]ach spouse shares an equal right of management and control over community property." ${ }^{329}$ In some states, either party may unilaterally alienate the community property. ${ }^{330}$ "Where either spouse, separately, may manage and control community property, a spouse has the right to manage and control a business operated by the other spouse as a sole proprietorship if the business is a community asset." 331 Community property law is therefore consistent with a finding that this factor weighs in favor of a business partnership.

\section{c. Capital Contributions}

If the partners in a traditional business partnership agree, personal services can be considered as non-cash capital contributions to a partnership. ${ }^{332}$ In most marriages, each individual brings different skills with different market values. In many marriages, especially among younger individuals, the asset that each brings to the partnership is human capital. By jointly sharing their human capital, they each can maximize their earning capacity throughout their lifetime and create capital for the partnership. Sharing of human capital in a marriage to further the interests of the economic external relations of the couple is consistent with the

of the couple as to the business nature of their marital economic activities and the fact that the profits from the family business were shared in gross rather than formally portioned into individual shares. $I d$. at $806-07$. In a community property state, this should not be a problem because the community property law then automatically divides the gross profits into individual spousal shares upon death or dissolution of the marriage.

326 UPA $\S 6(\mathrm{I}) ; I d . \S \mathrm{I} 8(\mathrm{e})$.

327 Callison \& Sullivan, supra note 311 , $\$$ : 13 .

328 Id.

329 4I C.J.S. Husband and Wife $\$ 3$ I6 (2011). Traditionally, the husband had the almost exclusive right to manage community property. See DE F UNIAK \& VAUGHN, supra note $238, \$ 113$. 330 Id.

33 I Id. (citing Dalton v. Superior Court of Arizona, 738 P.2d 365, 368 (Ariz. Ct. App. I 987)). 332 Schymanski v. Conventz, 674 P.2d 28I, 284-85 (Alaska 1983) (citing cases in Alaska, Wisconsin, and Utah); Callison \& Sullivan, supra note 31 I, 5:15. 
partnership concept of capital contribution. In addition, profits or fruits of separate property become community property and so do investments in the marriage partnership. ${ }^{333}$

3. Business for "Profit".-Despite the obvious hopes of those many couples who recite the pledge "for better, for worse, for richer, for poorer" at their wedding ceremony, determining whether the relationship between the parties to a marriage exists as a business for profit is problematic. ${ }^{334}$ The United States Supreme Court has recognized that "community property principle rests upon something more than the moral obligation of supporting spouse and children: the business relationship of man and wife for their mutual monetary profit." ${ }^{335}$ This is not merely rhetorical surplusage. Thirty-seven years later, in Rose v. Rose, the Court stated, "the community property concept is more akin to an amoral business relationship." 336 The sine qua non of partnership is that it is a commercial entity whose goal is to generate profits. ${ }^{337}$ Despite the element of "profit" as the dispositive motivating factor behind a partnership, the term profit is undefined in either the Uniform Partnership Act or in the Revised Uniform Partnership Act. ${ }^{338}$

"Profit" is defined in Black's Law Dictionary as "[t]he excess of revenues over expenditures in a business transaction[.]" "339 The dictionary definition of "business transaction" is even less helpful: "[a]n action that affects the actor's financial or economic interests, including the making of a contract." ${ }^{340} \mathrm{~A}$ literal reading of these definitions would bring all marital economic transactions (other than those for internal consumption) into the realm of "business for profit." As one scholar noted, "the family can be viewed as an economic subsystem that uses the paid and unpaid time of

333 See Oettinger v. Oettinger, 474 U.S. 91 2, 913 (1985); DeFuniaK \& VAUGHN, supra note $238, \S 71$.

334 See Lanza v. Lanza, 898 So. $2 \mathrm{~d} 280,285$ (La. 2005) ("A community enterprise is a business that is not a legal entity." (quoting LA. Crv. Code ANN. art. 2369.3 (20 I0))).

335 Wissner v. Wissner, 338 U.S. 655,660 ( 1950 ). In Wissner, the court went on to observe that "Venerable and worthy as [using community property to support spouse and child] is, it is not, we think, as likely to justify an exception to the congressional language as specific judicial recognition and particular needs, in the alimony and support cases." Id. The commercial nature of the community property marriage set it apart from the common law jurisdiction marriage where the court may have been willing to infer an intent by Congress not to preempt state law. See Rose v. Rose, 48 I U.S. 619, 632-33 (1987).

336 Rose v. Rose, 48 I U.S. 619, 632 (1987).

337 .RUPA § 202 (1997); UPA § 6(I) (1914). Contra Del. Code ANn. tit. 6, § I5-IoI(I I) (2005) ("'Partnership' means an association of two or more persons ... to carry on any business, purpose or activity." (emphasis added)).

338 Callison \& Sullivan, supra note 311 , at 255 n.I.

339 Black's Law Dictionary 1329 (9th ed. 2009).

340 Black's Law Dictionary 227 (9th ed. 2009). 
productive members to provide both market and home-produced goods and services for all members." ${ }^{341}$

It may be helpful to think of marriage in terms taught in a first year economics course. Recall the products possibility frontier, opportunity costs, and comparative advantage. Under principles of comparative advantage, ${ }^{342}$ couples can exploit the various skills and economic opportunities of each partner to grow the wealth of the domestic economy (marriage in this case). ${ }^{343}$ In purely economic terms, marriage allows specialization, increased economies of scale, and substitution of lower market-wage domestic productivity which permits the higher market-wage earner an increased opportunity to participate in the marketplace. ${ }^{344}$ To be blunt, historically this meant lower market-wage females specialized in domestic drudgery so that higher market-wage males had the "leisure" to place work first, work overtime, and dedicate themselves to wage-slavery. This model achieves one of the goals of marriage as an economic unit: the pursuit of every higher standard of living (increased income and wealth). This should be sufficient to establish a "for profit" motive in marriage associations. ${ }^{345}$

\section{B. Federal Tax Law Consequences}

The tax treatment of assets owned by the marriage-partnership under the proposed business-entity model is one possible area of concern. Probably the most salient difference among forms of business entities is how they are treated for federal tax purposes. ${ }^{346}$ Under federal tax law, a partnership is treated as a pass-through entity, and the income earned by the partnership whether distributed or not is taxed to the individual partners. ${ }^{347}$ Of note, the tax code has options for married couples engaged in the conduct of a business. For example, if both a husband and wife materially participate in a business and file a joint tax return they may elect. not to be treated as a partnership for tax purposes and would not have to file

341 Heather L. Ross \& Isabel V. Sawhill, Time of Transition: The Growth of Families Headed by Women 166 ( (975); see also Gary S. Becker, $A$ Theory of Marriage: Part I, 81 J. Pol. ECON. 813, 8I5 (1973) (using economic theory to understand cohabitation relationships: "“[M] arriage' simply means that they share the same household."). See generally GARY S. BECKER, A Treatise on the Family 20-30 (Harvard Univ. Press 2d ed., 1991).

342 See generally Dominick Salvatore, Economics 315-319 (4th ed. 1974).

343 See generally Elena Bardasi \& Mark Taylor, Marriage and Wages: A Test of the Specialization Hypothesis, 75 EcoNomica 569 (2008).

344 Id. at 570; Becker, supra note $34 \mathrm{I}$, at 815 .

345 James D. Gwartney et al., Microeconomics: Private and Public Choice 493 (12th ed. 2009) ("[P]rofit accrues only when the value of the good produced is greater than the value of the resources used for its production.").

346 Although state tax law is a significant aspect of any sound financial planning, it would add a level of complexity to the analysis that is well outside the scope of this article.

347 See 26 U.S.C. $\$ 701$ (2006). 
a partnership tax return. ${ }^{348}$ This shows that under some scenarios, a court could treat the marriage as also constituting a business entity partnership without tax consequences to the divorcing individuals. Alternatively, if treating the partnership as a traditional business entity partnership for tax purposes is more advantageous, the divorcing partners may elect to follow that route. ${ }^{349}$ These progressive tax rules do not yet apply to same-gender married couples or individuals living. in a cohabitation relationship. ${ }^{350}$ Consequently, couples outside a legally privileged marriage will have to rely on the default partnership tax rules. ${ }^{351}$ Still, though these couples will be required to file a partnership tax return because the partnership is passthrough entity for tax purposes, this is a mere formality and will not change the incidence of the tax burden. ${ }^{352}$

\section{JOINT-AUTHORSHIP OR WORK-FOR-HIRE}

In the previous section, this article demonstrated that a community property marriage might be reconceptualized in part as a business entity partnership. This section will analyze how federal copyright law treats works made by author-spouses in relation to the marital construct and whether copyright law provides for authorial forms that are consistent with treating the author-spouse as an employee of the community property entity partnership. As discussed previously, state domestic relations laws may render problematic the characterization of works created during marriage as works by an individual author. Courts have not properly considered whether other statutory forms of authorship contemplated by the Copyright Act might better meet the expectations of the creative couple. This section will analyze whether works created during marriage might be best considered as either joint-works or works-for-hire. Under modern copyright law, the initial ownership of the protected work belongs to either a natural person author or the hiring party as author, if it is a workfor-hire. The work-made-for-hire section of the Copyright Act deems the

348 Bonnie Lee, How to File Taxes When Your Spouse Is Your Business Partner, Fox Bus. Small Bus. Center (Nov. 25, $201 \mathrm{l}$ ), http://smallbusiness. foxbusiness.com/legal-hr/20 I I/I I/23/ husband-and-wife-run-business-how-to-file-taxes/; see 26 C.F.R. $\$$ I.469-5 (2012) (defining "materially participate").

349 Id.

350 See Windsor v. United States, 797 F. Supp. 2d 320, 322 (S.D.N.Y. 2011) (citing Defense of Marriage Act of 1996, Pub. L. No. 104-199, § 3, I 10 Stat. 2419, 2419 (1996)) (stating that the Attorney General of the United States is no longer defending the constitutionality of the definition of "marriage" found in section 3 of the Defense of Marriage Act).

351 See Windsor, 797 F. Supp. 2 d at 322.

352 See Albert Kritzer. et al., 3 International Contract Manual \$ 79: 195 (May 201 i) ("The taxable income of a partnership generally is computed in the same manner as that of an individual, except that certain deductions (for example, charitable contributions, personal exemptions, foreign income taxes, and net operating losses) are not allowed."). 
employer to be the legal author of works created for the employer without requiring any formalities such as a written, signed, assignment agreement. ${ }^{353}$ This section will analyze the legal authorial forms of work-made-for-hire and joint-work, the two forms that are relevant in the context of a marriage partnership under the 1909 Copyright Act, in order to explain why the problems presented in this article were not issues until the enactment of the 1976 Copyright Act. This section will then analyze the work-madefor-hire and joint-work authorial forms under the 1976 Copyright Act. Ultimately, this section will conclude that treating a community property marriage as a business entity partnership and deeming the author-spouse to be an employee of the marriage partnership entity is consistent with existing copyright law's rules governing works-for-hire.

\section{A. Copyright Act of 1909}

The 1909 Copyright Act is a significant starting point because in many areas the 1976 Copyright Act is merely a codification of the existing common law gloss on the 1909 Copyright Act. ${ }^{354}$ Unfortunately, the 1909 Copyright Act and its predecessors are not helpful to understand the context of the 1976 Copyright Act and state family property law. ${ }^{355}$ Pre-1976 Copyright Act, copyright law principles of ownership and authorship readily and naturally conformed to state law principles of personal property and family law. ${ }^{356}$

1. Work-Made-For-Hire.-The 1909 Copyright Act did not distinguish between works created by employees and works created by independent contractors so long as the work was created at the "instance and expense" of the employer. ${ }^{357}$ However, apart from the comedic or, satirical view of marriage as one partner firmly in control (usually the distaff partiner), copyrighted works created during a marriage were probably not comprehensible as works-for-hire commissioned by one of the spouses because " $t]$ he essential factor in determining whether an employee created his work of art within the scope of his employment as part of his employment duties is whether the employer possessed the right to direct and to supervise the manner in which the work was being performed." 358

353 See discussion infra Part V.B.

354 See, e.g., H.R. Rep. No. 1476, at 51 (1976), reprinted in 1976 U.S.C.C.A.N. 5659, 5664, 5679,5693 .

355 See Nevins, Jr., supra note 7 at 390.

356 See id. at 382 . 1966).

357 See Brattleboro Publ'g Co. v. Wịnmill Publ'g Corp., 369 F.2d 565, 567-68 (2d Cir.

$35^{8}$ Scherr v. Universal Match Corp., 4I 7 F.2d 497, 500 (2d Cir. 1969). 
2. Joint-Works.-The concept of "joint-work of authorship" exists in both the $1909^{359}$ and 1976 Copyright Acts. The most significant difference between the law of joint-authorship under the 1909 Copyright Act and the current law involves the present intent of the authors to create a joint-work. Under the 1976 Act, each author must have a present intent at the point of his or her respective contribution to the new work to merge his or her contribution with another's, so that the sum of the individual contributions results in a unitary whole. ${ }^{360}$ In contrast, there was no such requirement under the 1909 Act. ${ }^{361}$ Under the 1909 Copyright Act, the authors' intent did not have to be concurrent with the creation of the claimed joint-work. ${ }^{362}$ It was even possible for a work that was created with no intention that the work would ever become part of a joint-work to be merged into a jointwork if the author (or even a subsequent copyright owner) later assented to an addition or a change to the work by another author. ${ }^{363}$

3. Effect of the Copyright Act of 1909 on Transfers by Operation of Law.Fortunately, however, because the 1909 Copyright Act contained few formalities for the transfer of a copyright, ${ }^{364}$ allocation of property interests at the dissolution of the marriage never resulted in a quagmire of ownership disputes. The Act's lack of formalities also meant that states were free then to transfer copyright under operation of state law. ${ }^{365}$ The initial fixation of the work under the 1909 Copyright Act, if protected at all, was protected under state common law copyright, and this protection continued until general publication of the work. ${ }^{366}$ State law solely governed transfers or assignments of "copyrights" in unregistered works. ${ }^{367}$ In fact, while the assignment of a registered copyright had to be in writing, the assignment of

359 See generally Howard B. Abrams, I The Law of Copyright § 4:34 (20 I I).

36017 U.S.C. § IoI (2006); see Thomson v. Larson, 147 F.3d I95, 200-ol (2d Cir. 1998);

Childress v. Taylor, 945 F.2d 500, 507-08 (2d Cir. 199!).

36 I See Abrams, supra note $359, \S \S 4: 33-34$.

362 See, e.g., Shapiro, Bernstein \& Co. v. Jerry Vogel Music Co., 161 F.2d 406, 409-10 (2d Cir. 1946).

363 See, e.g., id. at 410.

364 Copyright Act of 1909, ch. 320, 35 Stat. 1075, 1084 (repealed 1976); see Magnuson v. Video Yesteryear, 85 F.3d 1424, 1428 (9th Cir. 1996).

365 See Fantasy, Inc. v. Fogerty, 664 F. Supp. 1345,1356 (N.D. Cal. 1987) (citing Brecht v. Bentley, 185 F. Supp. 890 (S.D.N.Y. 1960) (intestate succession), aff'd, 984 F.2d 1524 (9th Cir. 1993), rev'd on other grounds, 5 Io U.S. 517 (1994); I 3 C.J. Copyright and Literary Property $§ 245$ (1917) ("[T]he transfer of copyright may be effected either by operation of law or by voluntary assignment.").

366 Although this is commonly referred to as state common law copyright, some states had state copyright statutes. See, e.g., N.H. Rev. Stat. ANN. \$ 352: I (2008).

367 Mark S. Lee, Entertainment and Intellectual Property Law § 5:33 (20 I I). 
a state common law copyright could be made orally ${ }^{368}$ or through conduct, ${ }^{369}$ and at least one case held that the mere "possession of the manuscript by the plaintiff is evidence of his ownership . . .." ${ }^{370}$ As a creature of state law, the state could transfer the common law copyright through operation of state law. Many works that were ultimately federally registered, then, began their lives enjoying state common law copyright, and states have a right to establish the process by which state rights are divested. Because the federal registrant under the 1909 Act is the legal successor to the state common law copyright rights, the registrant was entitled to common law ownership rights initially conveyed by state law. ${ }^{371}$

\section{B. Copyright Act of 1976}

The 1976 Copyright Act established a new rubric to distinguish worksmade-for-hire from other forms of authorship and redefined the concept of joint-works. ${ }^{372}$ Now, the copyright to a work prepared by an employee for the employer that is within the employee's scope of employment is a workfor-hire. ${ }^{373}$ Additionally, a specially commissioned work that falls within one of nine statutorily defined eligible types of works and is made pursuant to an express written agreement signed by both parties (or their agents) also counts as a statutory work-for-hire. ${ }^{374} \mathrm{~A}$ copyrighted work that meets the statutory definition of work-for-hire results in the legal fiction that the employer or commissioning party is the author of the work; therefore, the title to the copyright initially vests in the employer or commissioning party. ${ }^{375}$

This legal fiction leads to the perhaps distasteful question of whether one can legally view the author-spouse as the employee of the marriage/

368 PATRY supra note $36, \S 5: 106$.

369 Jerry Vogel Music Co. v. Warner Bros., Inc., 535 F. Supp. 172, 175 (S.D.N.Y. 1982) ("It is well-settled, however, that the transfer of the 'common law copyright' in unpublished works did not have to be in writing but could be oral or inferred from conduct.").

370 Freudenthal v. Hebrew Publ'g Co., 44 F. Supp. 754, 755 (S.D.N.Y. 1942).

37 I See Self-Realization Fellowship Church v. Ananda Church of Self-Realization, 206 F.3d 1322, 1327-28 (9th Cir. 2000).

372 See Cmty. for Creative Non-Violence v. Reid, 490 U.S. 730, 737-38 (1989) (workmade-for-hire); Richlin v. Metro-Goldwyn-Mayer Pictures, Inc., 53 I F.3d 962, 968 (9th Cir. 2008), cert. denied, 555 U.S. I 137 (2009) (joint-work).

373 17 U.S.C. § 101 (2006) (defining "work made for hire"); id. § 201 (b); Cmty. for Creative Non-Violence, 490 U.S. at 738.

374 I 7 U.S.C. § I01 ("A 'work made for hire' is[] ... a work specially ordered or commissioned for use as a contribution to a collective work, as a part of a motion picture or other audiovisual work, as a translation, as a supplementary work, as a compilation, as an instructional text, as a test, as answer material for a test, or as an atlas, if the parties expressly agree in a written instrument signed by them that the work shall be considered a work made for hire.").

375 I 7 U.S.C. \$ 20 I (b) (2006); see generally Part V.B (discussing work-for-hire authorship). 
business partnership. Earlier in this article, marriage was divided into two distinct institutions: the romantic partnership (internal production and consumption) and the business partnership (external production and trade). ${ }^{376}$ The romantic partnership is responsible for the intimate and social aspect of the marriage, and the business partnership is responsible for the external commercial relations of the couple. An author-spouse could be considered an employee of the commercial partnership. Moreover, there is no requirement that the non-author-spouse or the marital partnership exercise control over the author-spouse. To the degree that control or the right of control was required under the 1909 Copyright Act, Congress in the 1976 Copyright Act rejected the 1909 Copyright Act case law that focused on control, right of control, or instance and expense tests as dispositive elements of whether a work is a work-for-hire and substituted the Restatement Second of Agency test. ${ }^{377}$

Revisiting the earlier hypothetical, ${ }^{378}$ Lexi, Annie, and Toby agreed that Lexi would provide Toby with financial support and that Annie would provide other in-kind support. In exchange, Toby would write a book, and when the book was published, they agreed to split the profits from the book (and any derivative works). The question is now to whom the copyright belongs as the author. There are two possibilities: either it belongs to Toby as the individual author or to the Lexi-Toby-Annie Partnership as a workfor-hire. ${ }^{379}$ The determination of authorship (and, necessarily, of initial ownership) under the Copyright Act will pivot on whether Toby was an employee working within the scope of his employment or an independent contractor. ${ }^{380}$

The United States Supreme Court interpreted the work-for-hire provisions of the Copyright Act in Community for Creative Non-Violence v. Reid. $^{381}$ The Court established that under the 1976 Copyright Act, the Restatement (Second) Agency $\S 220$ test is the appropriate multi-factor test to determine the employment status of an author. ${ }^{382}$ In determining whether a hired party is an employee or an independent contractor, Reid directs courts to evaluate a non-exclusive list of factors that includes

the source of the instrumentalities and tools; the location of the work; the duration of the relationship between the parties;

376 See discussion supro Part IV.A.

377 Cmty. for Creative Non-Violence, 490 U.S. at 742-43.

378 See discussion supra Part IV.A.

37917 U.S.C. § I0I (defining a "work made for hire"); 17 U.S.C. § 201 (a)-(b)..As there was no writing, ownership could not have been transferred by assignment to the partnership. See Effects Assocs. v. Cohen, 908 F.2d 555, 556-57 (9th Cir. 1990).

380 See Cmty. for Creative Non-Violence, 490 U.S. at 737-38; Warren v. Fox Family Worldwide, Inc., 328 F.3d I I 36, I 45 (9th Cir. 2003).

38I Cmty. for Creative Non-Violence, 490 U.S. at 737.

$3^{82}$ Id. at $75 \mathrm{I}-52$. 
whether the hiring party has the right to assign additional projects to the hired party; the extent of the hired party's discretion over when and how long to work; the method of payment; the hired party's role in hiring and paying assistants; whether the work is part of the regular business of the hiring party; ... the provision of employee benefits; and the tax treatment of the hired party. ${ }^{383}$

Courts usually will only consider the factors they deem relevant under the facts of the case. ${ }^{384}$ In Aymes $v$. Bonelli, the Second Circuit found that

[T]here are some factors that will be significant in virtually every situation. These include: (1) the hiring party's right to control the manner and means of creation; (2) the skill required; (3) the provision of employee benefits; (4) the tax treatment of the hired party; and (5) whether the hiring party has the right to assign additional projects to the hired party. These factors will almost always be relevant and should be given more weight in the analysis, because they will usually be highly probative of the true nature of the employment relationship. ${ }^{385}$

Concededly, the $\$ 220$ Restatement of Agency test is designed for skilled tradespeople, and its application in the context of copyright law and highly creative individuals (sometimes called dominant employees or superior servants) may be a bit strained. ${ }^{386}$ But courts have recognized that highly creative individuals may also be employees of the institutions that they themselves create and manage. ${ }^{387}$

Determining whether an author-spouse is an independent contractor or an employee of the marriage partnership in order to determine authorship and copyright ownership will require a fact specific analysis of each couple, each author, each marriage, and perhaps each work created within the marriage. Although this section will briefly mention all of the factors, in the real world a court would determine which factors were the most relevant under the facts of the specific case. Courts do not merely sum up the winners and losers on the individual factors when determining whether

383 Id.

384 E.g., Aymes v. Bonelli, 980 F.2d 857, 86 I (2d Cir. 1992). Of course, some courts weigh some factors more heavily than others. See id.

385 Id.

386 See Restatement (Second) of Agency § 220 (1958). The Restatement recognizes this problem by noting that " $[\mathrm{t}] \mathrm{he}$ word indicates the closeness of the relation between the one giving and the one receiving the service rather than the nature of the service or the importance of the one giving it." Id. $\S 220 \mathrm{cmt}$. a.

387 See Martha Graham Sch. \& Dance Found., Inc. v. Martha Graham Ctr. of Contemporary Dance, Inc., 380 F.3d 624, 639-40 (2d Cir. 2004). This is a common practice in Hollywood to hire talent through a "loan out" corporation where the talent is legally employed by a loan out corporation or entity that is also owned by the talent. See, e.g., Matthau v. Superior Court, 16. Cal. App. 4th 593, 601-02 (2007). 
a work is a work-for-hire under the Copyright Act. Rather, each factor is weighed individually.

The first factor, "the source of the instrumentalities and tools," will likely slightly favor finding the spouse to be an employee because the family will probably provide the tools (in Toby's case, perhaps a personal computer).

The second factor, "location of the work," is likely to favor finding the author-spouse an employee, if the author spouse works at home.

The third factor "the duration of the relationship between the parties," is likely to favor the author-spouse being the employee of the partnership.

The fourth factor, "whether the hiring party has the right to assign additional projects to the hired party," is likely to be weighed neutrally in the context of the marriage partnership. However, there would probably be an expectation of continued productivity and the creation of new works in the marriage.

The fifth factor, "the extent of the hired party's discretion over when and how long to work," is likely to be weighed neutrally. Authors write when the muse requires they write and may not have a set production schedule.

The sixth factor, "the method of payment," would be regular support from the non-author spouse and weigh in favor of the author-spouse being an employee.

The seventh factor, "the hired party's role in hiring and paying assistants," may to some degree be joint decisions and weigh in favor of finding the author-spouse is an employee.

The eighth factor, "whether the work is part of the regular business of the hiring party," weighs in favor of the author-spouse being an employee since one of the reasons that the partnership exists is to permit the spouse to create new works.

The final two factors, "the provision of employee benefits" and "the tax treatment of the hired party," will depend on the financial planning of each couple..$^{388}$

It is important to note that courts have been very generous to the putative employer when analyzing whether to consider a work as being a work-for-hire; as long as the work is created during the period of the employment and in some tangential manner furthered the interests of the employer, it is usually considered a work-for-hire, even if the work was 
created at home, outside office hours, at the employee's personal expense, and using the employee's own equipment: ${ }^{389}$

Many talented people, whether creative artists or leaders of major corporations, are expected by their employers to produce the sort of work for which they were hired, without any need for the employer to suggest any particular project. 'Instance' is not a term of exclusion as applied to specific works created within the scope of regular employment. It may have more significance in determining whether an employee's work somewhat beyond such scope has been created at the employer's behest or to serve the employer's interests[.]" 390

Therefore, the partnership (other spouse) might exercise only the most attenuated control or even no control over the author, yet the authorspouse could still be considered an employee under copyright law. ${ }^{391}$

If the spouse is an employee and the work is created is within the scope of the employment, ${ }^{392}$ then the legal author is the partnership. The legal status of a copyrighted work as either a work-for-hire or a work of a natural person has significant legal ramifications. First, a work-for-hire is not protected under the Visual Artists Rights Act. ${ }^{393}$ Second, the duration of copyright is different. Ninety-five to 120 years is the statutory term of protection for a work-for-hire. ${ }^{394}$. In contrast, the term for a work whose legal author is a natural person is the life of that author plus seventy

389 See Le v. City of Wilmington, 736 F. Supp. 2d 842, 848-5I (D. Del. 2010) (citing further supportive cases).

390 Martha Graham, 380 F.3 d at 640-4I.

391 See id. at 642 (citing Restatement (Second) of Agency $\$ 220$ (I) cmt. a (I 958)).

392 Because the Supreme Court adopted the Restatement of Agency test for employment in Cmry. for Creative Non-Violence; 490 U.S. at 740, it is likely to use the following definition from the Restatement to determine the scope of employment:

(1) Conduct of a servant is within the scope of employment if, but only if: (a) it is of the kind he is employed to perform;

(b) it occurs substantially within the authorized time and space limits;

(c) it is actuated, at least in part, by a purpose to serve the master, and

(d) if force is intentionally used by the servant against another, the

use of force is not unexpectable by the master.

(2) Conduct of a servant is not within the scope of employment if it is different in kind from that authorized, far beyond the authorized time or space limits, or too little actuated by a purpose to serve the master.

Id. at 740 (citing Restatement (SECOND) OF AgENCY $§ 228$ ( 1958 )). Therefore, it is likely that a court will find works made for the marriage partnership to be works made for hire within the scope of the author's employment.

393 Pollara v. Seymour, 344 F.3d 265, 269 (2d Cir. 2003); see I 7 U.S.C. § I I (2006) (defining a "work of visual art"); see also Nathan Murphy, Thème et VARAations: Why the Visual Artists Rights Act Should Not Protect Works-In-Progress, 17 UCLA ENT. L. Rev. I I0, 145-53 (2010) (discussing the economic implications of moral rights).

39417 U.S.C. $\$ 302$ (c) (2006). 
years. ${ }^{395}$ Finally, the author-spouse of a work-for-hire may not exercise termination of copyright transfer rights. ${ }^{396}$ This alone may make the workfor-hire authorial form more consistent with the share-and-share-alike community property model because the author-spouse cannot terminate the transfer of the work to the community and frustrate the non-author spouse's expectations under principles of community property law.

Under the 1976 Copyright Act, Congress vests authors and their statutory heirs with the right to terminate transfers of copyrights that were granted to third parties so as to recapture the alienated copyrights. ${ }^{397}$. Under some circumstances this is a potentially significant economic right. ${ }^{398}$ However, while some works will remain valuable forever, the vast majority of copyrighted works have only nominal economic value thirtyfive years after the initial transfer of the copyright by the author. ${ }^{399}$ The: community property marriage as business entity partnership proposed in this article is not obligatory; even if adopted, it will be merely a default rule. The marital couple could change from the default of marriage-asbusiness-partnership creating works-for-hire to the romantic author form of the marital relationship. Moreover, considering the relative economic insignificance of the work-for-hire doctrine on many creative works, the economic advantages, if any, to the marital community of retaining. the romantic authorship will be easily outweighed by the economic advantages of predictable copyright ownership and surety of rights. Further, the nonauthorial spouse will also not face the ever-looming threat of a termination of copyright transfer to the marital community.

\section{Conclusion}

Copyright law is federal law and as such it preempts inconsistent state laws. Several provisions of the 1976Copyright Act conflict with state domestic relations law and the allocation of community property in a divorce. Courts and commentators have gone to extraordinary lengths to avoid preempting these inconsistent state domestic relations laws. The easiest solution is for Congress to amend the. Copyright Act. However, despite numerous revisions of the Copyright Act, Congress has failed to make the necessary

395 Id. §302(a).

396 See id. $\$ 203$.

397 Id:; see Mills Music, Inc. v. Snyder, 469 U.S. 153, 173 n.39 (1985).

398 See, e.g., Siegel v. Warner Bros. Entm't Inc., 542 F. Supp. 2d 1098 (C.D. Cal. 2008). (terminating a transfer of "Superman"); Archie Comic Publ'ns, Inc. v. DeCarlo, 258 F. Supp. 2d 315 (S.D.N.Y. 2003) (discussing characters in Archie Comics).

399 See generally Eldred v. Ashcroft, 537 U.S. 186, 267-68 (2003) (Breyer, J., dissenting); Edward Rappaport, Cong. Research Serv., Copyright Term Extension: Estimating THE ECONOMic VALues 6-15 (May II, 1998), available at http://assets.opencrs.com/rpts/98144_199805 I I.pdf (describing such works as "outliers"). 
changes. Alternatively; there could be a significant change in state domestic relations law. There is little likelihood of this happening, though, because states are unwilling or unable to exclude an author-spouse's copyrights from community property as a species of separate property. Courts insist on treating copyrights as community property. Once an institution is defined as "marriage," it becomes the gold standard against which all other laws and legal institutions must be proven. ${ }^{400}$ Other institutions are measured against it, found wanting, and then the judge like Procrustes stretches or lops off the limbs of other bodies of law to force them to conform to an idealized romantic norm of marriage. Copyright law has suffered such a fate-one court made a non-author spouse a joint-owner ${ }^{401}$ while another court severed the author's statutory copyrights from the economic benefits from the exercise of these property rights ${ }^{402}$ - and since the other six community property states have not yet spoken; there is still room for new judicial theories of copyright ownership in community property states.

This article suggests harmonizing copyright law and community property law through the artifice of deconstructing a community property state marriage into its two constituent elements: a romantic partnership that produces goods and services for it internal consumption and a business entity partnership that produces goods and services for trade and profit. This novel solution has the advantage of not analytically subordinating federal copyright law to state domestic relations law. Moreover, it can be accomplished without a change in statutory law. The proposed reconceptualization of the community property marriage as a business partnership is consistent with Uniform Partnership Act and the Revised Uniform Partnership Act, and it is also consistent with the economic realities during marital dissolution proceedings involving an author-spouse in many community property jurisdictions. Under this reconceptualization, the community author-spouse is now treated as an employee of the marital community partnership. The Copyright Act has provisions for allocating interests in a work-for-hire. In the case of a work-for-hire, the employer is legally the author. Since under the Copyright Act the communityproperty-marriage-as-business-partnership is deemed to be the author for all purposes, the allocation of the economic interests in copyright in a divorce action is the same as the allocation of the copyright interests in dissolving a conventional business entity partnership. The business partnership work-for-hire model also does not rely on the laws of any one state so it can be applied in different states having different domestic relations laws. Moreover, this model promotes a uniform distribution of the copyright interests since copyrighted works created as works-for-hire are

400 See United States v. Lopez, 514 -U.S. 549, 564-65 (1995) (stating family law appears to limit Congressional power under the Commerce Clause).

401 In re Marriage of Worth, 24 I Cal. Rptr. 135, 137 (Cal. Ct. App. 1987).

402 Rodrigue II, 218 F.3d 432, 435-36 (5th Cir. 2000). 
not subject to the author-spouse's termination of copyright transfer rights. Therefore, this solution recommends itself because it relies on the wellestablished partnership model that is consistent with the goals of property equality in community property jurisdictions, and it is consistent with the policies expressed by Congress in the Copyright Act. 